\title{
Interactive Design to Encourage Energy Efficiency in Offices: Developing and Testing a User-Centered Building Management System Based on a Living Lab Approach
}

\author{
Carolin Baedeker ${ }^{1, *}$, Julius Piwowar ${ }^{1}\left(\mathbb{D}\right.$, Philipp Themann ${ }^{1}$, Viktor Grinewitschus ${ }^{2}$, \\ Benjamin Krisemendt ${ }^{2}$, Katja Lepper ${ }^{2}$, Christina Zimmer ${ }^{3}$ and Justus von Geibler ${ }^{1}$ \\ 1 Research Unit Innovation Labs, Division Sustainable Production and Consumption, \\ Wuppertal Institute for Climate, Environment, and Energy, 42103 Wuppertal, Germany; \\ julius.piwowar@wupperinst.org (J.P.); philipp.themann@wupperinst.org (P.T.); \\ justus.geibler@wupperinst.org (J.v.G.) \\ 2 EBZ Business School-University of Applied Sciences, 44795 Bochum, Germany; \\ v.grinewitschus@ebz-bs.de (V.G.); b.krisemendt@ebz-bs.de (B.K.); k.lepper@ebz-bs.de (K.L.) \\ 3 Twistid GmbH \& Co. KG, 40545 Düsseldorf, Germany; zimmer@twistid.de \\ * Correspondence: carolin.baedeker@wupperinst.org; Tel.: +49-202-249-2119
}

Received: 20 July 2020; Accepted: 22 August 2020; Published: 26 August 2020

check for updates

\begin{abstract}
Many technical solutions have been developed to enhance the energy efficiency in buildings. However, the actual effectiveness and sustainability of these solutions often do not correspond to expectations because of the missing perspective of design, user's real needs, and unconsidered negative side effects of their use (rebounds). With the aim to help address these challenges, this paper presents results of a longitudinal living lab study and proposes a user-centered building management system (UC-BMS) as a prototype for office buildings. Based on mixed methods, UC-BMS was co-developed, tested, and evaluated in Germany in up to six office buildings, 85 offices, and within two heating periods. The results demonstrate that such user-oriented approach can save up to $20 \%$ of energy while maintaining or even improving comfort and work productivity. The findings show three main areas of intervention and elements of UC-BMS: (1) How interactive design and feedback systems (e.g., air quality) can stimulate ventilation practices and energy efficiency in offices and (2) supporting heating system optimization e.g., by better understanding office behavior. (3) Finally, an office comfort survey was conducted to enable communication between facility management and office users and thus limiting complaints and adapting the heating system towards actual office user needs.
\end{abstract}

Keywords: interactive design; energy efficiency; feedback systems; smart office; sustainable living labs

\section{Introduction}

About $32 \%$ ( $8.8 \mathrm{Gt} \mathrm{CO}_{2}$ emissions) of final energy consumption comes from the building sector and energy demand is expected to double, while $\mathrm{CO}_{2}$ emissions will rise by $50-150 \%$ by the middle of the century [1] (p. 22). To enhance energy efficiency performance in buildings, many technical innovations have been developed. Advances in technology and the building characteristics offer improvements for lower energy consumption in buildings and include new building codes and appliance standards [2,3], but also lifestyle and individual behavior, which can reduce energy demand by up to $20 \%$ in the short term and up to $50 \%$ by mid-century [1] (p. 23). This is discussed as the energy use performance gap, meaning that while "the building might satisfy building regulations at the design stage, a gap frequently 
occurs between the energy use predicted at the design stage and the energy used when a building is operational" [4] (p. 31). It is here that the influence of building users widely acknowledged [5-8]; however, their precise impact is less certain.

In this context, studies focus on interfaces and smart feedback devices, which seek to influence people's energy use $[9,10]$ and aim to reduce resource use and greenhouse gas (GHG) emissions in buildings [11,12]. It has been shown that the ventilation behavior may be more relevant for the energy consumption than the year of construction of the building [13]. In addition, Buhl et al. 2016 [14] explored the relevance of users' well-being and comfort temperatures for enabling routine changes in heating practices while, the advantage of energy saving strategies in offices can improve productivity and wellbeing at the workplace [15].

However, recent investigations have shown that interventions with the intention of lowering energy consumption often fail. Buchanan et al. $[16,17]$ demonstrated in their analyses of in-home-displays for feedback on energy consumption feedback that there is limited evidence to suggest providing data on the energy flow alone is sufficient to reduce energy consumption. They propose that triggering user engagement directly should be a part of smart metering systems to reduce energy consumption in households. Furthermore, it is shown that smart thermostats also cannot fulfill their potential in saving energy and result in increasing energy consumption due to incorrect use [18].

Reasons for this include the poor understanding of user needs and emotions in real-life contexts $[19,20]$. Furthermore, behavioral-oriented solutions may even stimulate reactance [21] and feelings of manipulation and control (paternalism) [22,23] and developed solutions do not meet the initial expectations because of unexpected patterns in the usage phase, where efficiency gains are counteracted by increases in consumption or sustainable actions are balanced with unsustainable practices (the rebound effect [24-26]. Finally, solutions can have difficulties accounting for changes in behavior because interventions are rather "rhetorical," supporting "green" attitudes but not leading to actual and intended behaviors (the "attitude-to-action-gap") [27-29].

Against this background, the authors hypothesize that limited acceptance and incorrect use will increase in line with the growing complexity of smart systems. In this regard, an increasing focus on user-centered research design to consider the human factor(s) more deeply (e.g., comfort and user experience) is proposed. This aims to create a better understanding of energy efficiency and design interventions in the context of office buildings. Hence, the objective of this paper is to propose a concept for implementing energy efficiency and behavior change in office buildings utilizing a user-centered building management system (UC-BMS). The research questions are as following:

- How can design intervention support to deliberately shape behavior to encourage energy efficiency in office buildings?

- What potential energy savings could be reached with a user-centered building management system (UC-BMS)?

- To what degree office behavior and practices can be changed by design interventions and thus support energy efficiency in office buildings?

The paper is structured in the following way: In Section 2, the conceptual approach is described including design approaches for behavior change and the background on sustainable living labs (SLL). The research design with six main research steps is presented in Section 3. Thereby, the research is oriented towards the three main iterative phases of a sustainable living lab (SLL) including quantitative and qualitative methods. The results and discussion in Section 4 summarizes the literature review findings on main design interventions for encouraging sustainable behavior and energy efficiency in office buildings (Section 4.1). Furthermore, results on potential energy savings are based on an estimation including three different scenarios that focus on lowering the room temperature in the offices outside and during working hours (Section 4.2). In addition, and beyond the (technical) optimization of the central heating system, Section 4.3 presents findings of the prototyping and the experiment with the user-oriented assistant system (called "Piaf") for encouraging energy efficient ventilation 
practices. Finally, results are presented on testing and evaluating a survey on the comfort level of temperature in offices ("Comfort Check"); thus, providing first insights on how to establish a (digital) communication platform between facility management and office users (Section 4.4). The article ends with a conclusion (Section 5) on user-centered building management system (UC-BMS) and suggestions for further research.

\section{Conceptual Approach}

\subsection{Interactive Systems and Design for Behavior Change}

Currently, interactive systems are mainly discussed in the research field of human computer interaction (HCI) [30]. In recent years, interactive systems and interactive design have also been discussed to deliberately influence people's behavior, for example interfaces and dashboards that visualize and feedback the individual energy use [31]. Interactive systems encompass products, services, and environments, both digital and physical—a system [32] that is meant to shape what we feel, think, and do, and inevitably influence our experience and behavior [33]. However, all products are interactive, allowing for and requiring interaction, while all products can contribute to, stage, shape, facilitate, or enable experiences and behavior.

"Behavior change" as a design objective has become fashionable in recent years-commercially, politically, and academically_addressing everything from fitness tracking, to getting passengers to board trains more efficiently and improving public services through concepts such as the application of the Nudge Theory [34].

Although design encourages a specific behavior, for example a chair affords sitting and a cup with a handle affords a certain a way of drinking, "behavior change" by design is a controversial discussion [35]. For instance, there is the described relationship of "affordance" [36], which addresses designers' concern about making possible uses of their products (e.g., the chair or cup) immediately obvious or intuitive [37]. This concept was originally proposed by the psychologist, James Gibson, to denote what the environment "offers the animal, what it provides or furnishes, either for good or ill" [38]. The concept was then introduced to the field of design, and eventually HCI, by Donald Norman (1988) [37], in which he defines affordances as: "the perceived or actual properties of the thing, primarily those fundamental properties that determine just how the thing could possibly be used".

On the other hand, psychological research on human behavior is becoming more and more accepted in design and public policy resulting in approaches such as "Persuasive Technology" [39] or "Nudge" [34]. Experts in various fields have investigated the epistemological, ethical, and legal underpinnings of the idea of persuasive and paternalist interventions; that is, products or policies that restrict the choices of individuals in their own interests and without their consent $[40,41]$. However, these interventions can infringe a key principle of liberal societies; that people are best placed to know their own interests [42]. Nevertheless, research argues that persuasive and paternalist interventions may be considered justifiable under circumstances, for example if it is possible to identify failures in people's reasoning [41].

In the context of sustainability research, behavior change by design is discussed in terms of interventions that stimulate sustainable patterns in everyday life. Thereby, the degree of intervention varies with the boundary of how the 'problem' is framed, whether it is at the individual level of user-product interaction [39] or part of a more systemic societal transition [43,44]. The concept of Design for Sustainable Behavior (DfSB) $[39,45,46]$ and Design with Intent [47] explore the role of design to deliberately influence user behavior. These behavioral-oriented models suggest ways of product-user interaction by interventions enabling change of behavior and attitude. These interventions are criticized by Kuijer and Bakker 2014 [48] as it delegates responsibility to individual and limits consideration of a larger system perspectives that address complexity and dynamics of daily life situations.

Furthermore, Aesthetics of Friction [22], Transition Design [43], and Practice-oriented Design [49]) look at slow-changing habits (routines) as a main driver determining consumption patterns and 
related resource intensity. Nevertheless, their focus goes beyond single product user interactions and explore socially shared practices. These approaches are based on Practice Theory [50,51], Self-Regulation Theory [52], and Activity Theory [53] and can be linked to Experience Design [54]. Thereby, practices are embedded in larger, socio-technical contexts and thus enable designers to develop a better understanding on a larger-potentially systemic — change [55] and to discuss how the product may then conflict with value systems. In this regard "Transition Design" aims at changing values towards sustainable development. It can be used in research to combine design methods and sustainability science, to promote science-based competences and co-creation in Living Labs or real-life laboratories [56-59].

According to Lockton et al. 2012 [60] design interventions can be structured into different categories by applying systems theory [61,62] to human-computer interaction [63]. As a result, a simplified set of three interaction archetypes evolved with the aim to move users from a less engaged mindset, towards a more reflective, motivated, thoughtful relationship with a product, service, or environment [60]. Table 1 summarizes the three types of interventions [60,64].

Table 1. Overview of three types of interventions (derived from $[60,64]$ ).

\begin{tabular}{|c|c|}
\hline Coercive Interventions & $\begin{array}{l}\text { Assumes that the user does not think beyond basic reflex responses } \\
\text { coming from the design stimulus. There is no need for understanding, } \\
\text { design silently structures behavior (e.g., microwave works with door } \\
\text { closed only). Users follow the designers' behavior specification without } \\
\text { necessarily being aware of it. The aim is not to provide users with a } \\
\text { range of choices, but force functions [65], to make a job easier and for } \\
\text { providing safety. }\end{array}$ \\
\hline Persuasive Interventions & $\begin{array}{l}\text { Assumes that users are bounded rational [66] and want the easiest way } \\
\text { to do things and to minimize cognitive expenditure. Thus, user } \\
\text { decision-making addresses automatic and unaware aspect of human } \\
\text { behavior with the goal of playing along with people's natural actions } \\
\text { and reactions [67]. This model of a user takes "shortcuts" rather than } \\
\text { thinking deeply about problems and how to solve them [60]. The aim is } \\
\text { to help people navigate in available options (choice architecture) and to } \\
\text { pick the best result due to reducing complexity (archiving simplicity) } \\
\text { without forbidding, banning, or hiding any options or significantly } \\
\text { changing their economic incentives [67]. In behavioral economics, this } \\
\text { approach is known as Nudge [34] in design as Persuasive [46]. }\end{array}$ \\
\hline Reflective Interventions & $\begin{array}{l}\text { Assumes that users reflect on actions and change their behavior in } \\
\text { response to reasoned arguments and persuasive rhetoric [68]. Thus, } \\
\text { users are not acting on impulse and automating processes as utilized by } \\
\text { "Nudge". Mostly this relies on the provision of feedback to allow users } \\
\text { to explore the implications of their actions. Choice and reflection are left } \\
\text { to the user and is meant as the beginning of an explicit process of } \\
\text { meaning-making. Meaning addresses user's mental activities, emotions, } \\
\text { and motivational knowledge [51] to e.g., implement changes in } \\
\text { consumption practices [69]. }\end{array}$ \\
\hline
\end{tabular}

\subsection{Sustainable Living Labs (SLL) and Human-Centered Design}

Human-centered research and design is increasingly conducted within Living Labs settings in order to address problems of user acceptance, incorrect usage, and other unintended side effects of human technology interactions and in the event of fundamental innovations or high market and technology uncertainty $[25,70]$.

Living Labs can be defined as a "user-centered, open innovation ecosystem based on a systematic co-creation approach, integrating research and innovation processes in real-life communities and settings, for example within an office building [71]. They are meant to enable prototype tests in the real world (in contrast to simulations) and thus allow for better clarification of contextual and human factors as well as to reduce risks of being trapped by wrong (personal) perceptions [56,72]. 
In sustainable living labs (SLL), social and environmental effects of innovations are measured and optimized [72-74]. Liedtke et al. 2015 [72] and Baedeker et al. 2017 [74] consider SLL research to be an effective way to create and implement new eco innovations due to stronger focus on users' behavior, habits, or practices. The core of SLL is the co-development and testing of sustainable product and service innovations to provide insights into the usability and adoption for industry, public, and academic stakeholders [24,75]. The potential of SLL has been demonstrated in various cases including energy efficiency solutions [75].

According to Liedtke et al. 2015 [72] there are three iterative phases of research and development in SLL: (1) Insight research focuses on the analysis of the status quo of user behavior; (2) prototyping includes stakeholders in research, especially the end-user and business partners, to develop sustainable product and service innovations; and (3) testing provides an extended investigation of the latest innovations.

Living Lab research is multidisciplinary and strongly supports mixed method approach to create a better understanding of user habits and practices, for example through in-field experiments gathering behavioral information, indoor room temperature, and $\mathrm{CO}_{2}$ concentrations collected by sensory technologies [76]. Furthermore, participants of field tests can be interviewed for example on their experiences and exceptions to gain a better understanding of experimental results.

Depending on the research task and innovation phase, users and stakeholders are either actively and initially involved in the innovation process or are central to the process. Both can be supported by human-centered design (HCD) as it is an analytical and creative approach. However, there is no common definition on human or user-centered design and the term refers to many other (e.g., Participatory Design [77]). To emphasize the impact on stakeholders who might not typically be considered as users, ISO 9241-210:2010 [78] uses the term "human-centered" rather than "user centered" [79]. The aim is to ensure that the result fits human desires, needs, and capabilities, whereas engineering-driven design for example tends to emphasize reliability, cost, and efficiency [36].

According to the European Commission 2009 human-centered design is identified as one of the key elements of innovation development. However, according to Norman and Verganti 2014 [80], HCD has also its limitations if the emphasis is on incremental improvements enabled by iterated observation, ideation, and testing. Also, Kuijer and Bakker 2015 [48] or Liedtke et al. 2019 [43] suggest a broader system perspective that suggests applying practice-oriented Design or Transition Design as $\mathrm{HCD}$ can pay too little attention to complexity and dynamics of daily life and the context given by cultural, social, and material surroundings in which products are used.

\section{Research Design: Methods and Data}

This section presents the research design of the paper. It follows a mixed method combining quantitative and qualitative approaches as recommended by Living Lab research. The results are based on the two German research projects "EE Office" (2016-2019) and "Zukunft Bau" (2017-2019) [81,82] including (depending on the research phase) up to six buildings and 85 offices in Berlin and Bonn. In total, there are six research steps oriented towards the three main iterative phases of a sustainable living lab (SLL) (Table 2).

Table 2. Overview of the research phases and steps including applied methods and scope.

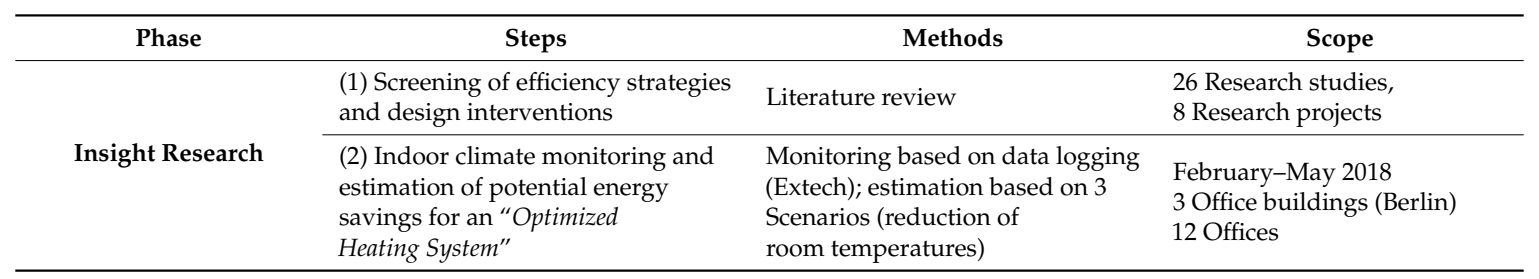


Table 2. Cont.

\begin{tabular}{|c|c|c|c|}
\hline Phase & Steps & Methods & Scope \\
\hline Prototyping & $\begin{array}{l}\text { (3) Co-creation of prototypes and } \\
\text { assessment of their } \\
\text { overall acceptance }\end{array}$ & $\begin{array}{l}\text { Co-creation workshop and survey } \\
\text { on the overall acceptance incl. } \\
\text { usability, user experience, } \\
\text { ergonomic and } \\
\text { cognitive perception }\end{array}$ & $\begin{array}{l}\text { Workshop }(\mathrm{N}=12, \text { Bochum }) \\
\text { Survey }(\mathrm{N}=26, \text { Bonn })\end{array}$ \\
\hline \multirow{3}{*}{ Testing \& Evaluation } & $\begin{array}{l}\text { (4) Testing and evaluation of the } \\
\text { interactive feedback system "Piaf" }\end{array}$ & $\begin{array}{l}\text { Real-world experiment, } \\
\text { quantitative assessment on } \\
\text { (changes) of ventilation practices }\end{array}$ & $\begin{array}{l}\text { December 2018-April } 2019 \\
3 \text { Office buildings (Berlin) } \\
27 \text { Offices (Piaf) } \\
12 \text { Offices (no Piaf) }\end{array}$ \\
\hline & $\begin{array}{l}\text { (5) Testing and evaluation of the } \\
\text { "Comfort Check" }\end{array}$ & $\begin{array}{l}\text { Daily Survey on the individual } \\
\text { room climate comfort level }\end{array}$ & $\begin{array}{l}\text { March-April } 2018 \\
3 \text { Office buildings (Bonn) } \\
24 \text { Office users }\end{array}$ \\
\hline & $\begin{array}{l}\text { (6) Qualitative assessment of the } \\
\text { design interventions }\end{array}$ & Interviews and Workshop & $\begin{array}{l}\text { Before and after the testing } \\
\text { Piaf: } \\
\text { Interviews }(\mathrm{N}=21 \text {; Berlin }) \\
\text { Workshop }(\mathrm{N}=26 \text {; Berlin })\end{array}$ \\
\hline
\end{tabular}

\subsection{Phase 1 Insight Research}

Step 1: Screening of efficiency strategies and design interventions. Based on a literature review strategies and design interventions that focus on energy efficiency and behavior change in office buildings were explored. In total, 26 studies and 8 research projects were identified and mapped towards the four design intervention categories (Coercive, Persuasive, Reflective, Others; see Section 2.1) and evaluated based on a 3-level ranking (high, medium, low) focusing on its potential for behavior change and energy efficiency in context of office buildings.

Step 2: Indoor climate monitoring and estimation of potential energy savings of an optimized heating system. The quantitative assessment focused on indoor climate factors that can influence energy consumption including relative humidity $(\%)$, outdoor and indoor temperature $\left({ }^{\circ} \mathrm{C}\right)$ as well as air quality $\left(\mathrm{CO}_{2}\right.$ concentrations in $\left.\mathrm{ppm}\right)$. Monitoring was carried out with sensor data logging technology (Extech Model SD800) at one-minute intervals. The monitoring provided insights for analyzing the existing heating system. The estimation of potential energy saving based on an improved heating system and were explored by 3 scenarios focusing on reducing the temperature in an effective, smarter way. In total, the monitoring and estimation were made in Berlin for three buildings (12 offices) and in the heating period February until May (2018).

\subsection{Phase 2 Prototyping}

Step 3: Co-creation of prototypes and assessment of their overall acceptance. In collaboration with designers, technical experts, and potential users, three prototypes were developed and evaluated. Thereby, the focus was beyond technical feasibility to also address the overall acceptance of the prototypes (e.g., style, emotional product attachment). These evaluations were conducted due to one co-creation workshop $(\mathrm{N}=12$, Bochum) and one anonymous online survey $(\mathrm{N}=26$, September 2018 in Bonn) with potential users.

\subsection{Phase 3 Testing and Evaluation}

Step 4: Testing and evaluation of the interactive feedback system "Piaf". The experimental, quantitative study aimed at providing results on the user interaction with "Piaf" and its effects on ventilation practices (behavior change) as well as environmental impacts. "Piaf" was tested in 27 offices and for four months (December 2018-April 2019). The tests shall add a more practice and design-oriented approach to the growing literature on the effects of design interventions including eco-feedbacks.

Step 5: Testing and evaluation of the "Comfort Check". The individual room climate comfort level was evaluated with 24 office users and based on survey over 4 weeks (March to April 2018) in Bonn. The objective of the survey was twofold: First, to receive understanding of the room temperature 
comfort level. Therefore, the survey was sent out twice a day and by email. Participants were asked to state their actual perception of the temperature in the office within a five-level scale (too warm to too cold). Second, to explore the acceptance of the "Comfort Check" as a potential feature of a communication platform; as part of UC-BMS. Thereby the aim was to enable interaction between office users and facility management e.g., to limit complaints.

Step 6: Qualitative assessment of the design interventions supported better understanding of experimental results as well as exploring the strategies and design interventions for energy efficiency and behavior change. In total, 21 participants (19 office users and 2 facility management) were interviewed on their expectations and experiences (functionality, usability, user experience) before and after use of the interactive system "Piaf". The workshops involved 26 participants.

\section{Results and Discussion}

\subsection{Literature Review: Design Intervention Encouraging Behavior towards Energy Efficiency}

This section presents the results of the literature review (Phase One: Insight Research-Step 1). Results showed that there are 16 patterns that can support the development of strategies and design interventions (Table 3). The reviewed literature indicates that today's energy efficiency strategies mainly focus on technical adjustment and modernization of the system technology [83] or at promoting sustainability-relevant routines in buildings and at the workplace [14,84].

Thereby, results suggest merely implementing technical automations (coercive intervention) is not sufficient to change behavior $[64,85]$. The risks are that users do not reflect on their behavior or perceive a poor and frustrating experience when their expectations conflict with the priorities of the system e.g., automation of office temperature. Additionally, forcing behavior to follow a specific practice can lower the likelihood of individuals engaging with the intended action (reactance; [21]) or even lead them to engage in the exact behavior that one wanted to abandon $[33,68]$.

Furthermore, information materials such as brochures, flyers, and workshops also have difficulties to helping to achieve potential energy savings [84,86,87], because they rather help "good intentions" (e.g., "I should ..." ) and "green attitudes", but may not lead to intended behavior (see "attitude to action gap" [27-29]. Hence, a combination of different (interactive) interventions is suggested to effectively address energy efficiency and energy-saving behavior in offices, including:

- $\quad$ Temporal Rhetoric Feedbacks that remind people about energy saving strategies, using prompts or sticky notes at the desktop [84,87].

- Eco Data Feedbacks that illustrate individual's energy consumption $[10,88]$.

- Social Normative Feedbacks that compare individual energy consumptions with others' energy consumption (e.g., neighbors) [89,90].

- Gamified Feedbacks that utilize persuasive mechanisms to translate abstract data into iconic symbols and a gamified experience to initiate long-term engagement (e.g., towards challenges, rewards, levels, emotional attributes [91-93]).

- Frictional Feedbacks that aim to engage users on procedural level and in interaction with a physical object (also called "Aesthetics of Friction"; "Transformational Troublemaker" or "Transformational Products"). Here, situated, unwanted habits should be interrupted, and alternative, simple action plan suggested [22,27]. An example of a "Transformational Troublemaker" is a special key holder that suggests users to use a bike instead of a car: If the user grabs the bike key, nothing happens. If the user grabs the car key, the "key holder" releases the bike key, which then drops to the floor. Obviously, one can just leave it there. However, when picking up the bike key, it confronts users with a choice: Car or bike. 
Table 3. Summary of literature review: Design interventions and its potential for behavior change.

\begin{tabular}{|c|c|c|c|c|}
\hline Intervention Types & Design Pattern & Examples & Potential (Low, Medium, High) & Reference \\
\hline \multirow{5}{*}{ COERCIVE } & Automation & $\begin{array}{c}\text { Interlock (AC turns off with open } \\
\text { window); automation based on } \\
\text { usage data }\end{array}$ & $\begin{array}{l}\text { High, if complementary to } \\
\text { reflective interventions. }\end{array}$ & [95-100] \\
\hline & Choice editing & Banning energy inefficient devices & $\begin{array}{l}\text { High, if complementary to } \\
\text { reflective interventions. }\end{array}$ & [94] \\
\hline & Feature deletion & Removing stand-by buttons & $\begin{array}{l}\text { High, if complementary to } \\
\text { reflective interventions. }\end{array}$ & [94] \\
\hline & Matched affordances & $\begin{array}{l}\text { New fitting design for bulbs; old, } \\
\text { inefficient bulbs do not match to } \\
\text { present lamps. }\end{array}$ & $\begin{array}{l}\text { High, if complementary to } \\
\text { reflective interventions. }\end{array}$ & [94] \\
\hline & Hiding things & Heating control & $\begin{array}{l}\text { High, if complementary to } \\
\text { reflective interventions. }\end{array}$ & [94] \\
\hline \multirow{4}{*}{ PERSUASIVE/NUDGE } & Incentives/Gamification & $\begin{array}{l}\text { (Financial) rewards, vouchers, } \\
\text { rankings }\end{array}$ & $\begin{array}{l}\text { Low if there is a lack of financial } \\
\text { resources; Low if vouchers incl. } \\
\text { unattractive registration; High if } \\
\text { gamified experience }\end{array}$ & {$[87,94,96,97,100-105]$} \\
\hline & Default option & 2-page print & High & [94] \\
\hline & $\begin{array}{l}\text { Reframing by } \\
\text { aesthetics }\end{array}$ & $\begin{array}{l}\text { Aware Puzzle Switch: interrupt } \\
\text { aesthetic pleasure of light switch } \\
\text { when the light is on. }\end{array}$ & Medium & [106] \\
\hline & Perceived affordances & $\begin{array}{l}\text { The design of a recycling bin } \\
\text { influences recycling compliance }\end{array}$ & Medium & [107] \\
\hline \multirow{5}{*}{ REFLECTIVE } & Rhetoric Feedbacks & $\begin{array}{l}\text { Prompts, requests/ reminders, } \\
\text { sticky notes at desktop }\end{array}$ & $\begin{array}{l}\text { Low if permanent } \\
\text { High if temporarily }\end{array}$ & $\begin{array}{c}{[84,87,96-100,102-106,} \\
108-110]\end{array}$ \\
\hline & Data/Eco Feedbacks & $\begin{array}{l}\mathrm{CO}_{2} \text { scoring, visual dashboard } \\
\text { with individual } \mathrm{CO}_{2} \text {, monitoring }\end{array}$ & High & $\begin{array}{c}{[64,83,86,96,100,101} \\
109,111-116]\end{array}$ \\
\hline & Social Feedbacks & $\begin{array}{l}\text { Comparing own } \mathrm{CO}_{2} \text { emission } \\
\text { with others }\end{array}$ & High & {$[86,101,111-116]$} \\
\hline & Gamified Feedbacks & Eco Island Game & High & {$[117,118]$} \\
\hline & $\begin{array}{l}\text { Frictional } \\
\text { Feedbacks }\end{array}$ & Pleasurable Troublemakers & High & [95] \\
\hline \multirow[t]{2}{*}{ OTHERS } & $\begin{array}{l}\text { Information } \\
\text { materials }\end{array}$ & $\begin{array}{l}\text { Posters, flyers including } \\
\text { recommendations on energy } \\
\text { saving }\end{array}$ & $\begin{array}{l}\text { Low: Information only without } \\
\text { interaction and user integration }\end{array}$ & $\begin{array}{c}{[84,86,87,97-105,108,} \\
112,114,115,119]\end{array}$ \\
\hline & $\begin{array}{l}\text { Qualification and } \\
\text { educational } \\
\text { activities }\end{array}$ & Workshops, seminars & High-Medium & $\begin{array}{c}{[84,87,96,99,100,102} \\
104,112,115]\end{array}$ \\
\hline
\end{tabular}

Some discussed risks of these persuasive mechanisms and interventions are that researcher and designer become part of a 'nanny state', making moral decisions about 'what's best' for users [94]. Furthermore, users could perceive interventions as manipulation or losing control and autonomy (paternalism). Risks of these feedback interventions are, for example, decreasing motivation to interact with the system; it might lose its charm and will be ignored over time. Furthermore, negative experiences and rejection could arise if systems are designed to be too smart or strict (reactance, feeling of manipulation) [95].

\subsection{Monitoring and Estimation: Optimizing the Heating System Operations towards Energy Efficiency}

This section presents the results of the (i) monitoring and (ii) estimation of potential energy savings of an optimized heating system (Phase One: Insight Research-Step 2). Furthermore, the findings are discussed in context of the (iii) workshop results (Step 6).

In total, the analysis and estimation were made for three buildings in Berlin ( $\mathrm{N}=12$ offices) and within the heating period of February until May in 2018. The three buildings have very different requirements in terms of both system technology and building physics. Building A complies with a passive house standard and is equipped with a building management system (BMS) including controlled room temperature and ventilation as well as possibilities to open windows. Both building $B$ (renovated) and building C (not renovated) are old buildings where the room temperature is controlled via thermostatic valves and ventilation can be made by opening the window. There is no controlled ventilation system in building $B$ and $C$.

(i) Monitoring of the existing heating system 
The efficiency of the existing heating system was analyzed based on measurements including the ratio of indoor and outdoor temperature and by focusing on the weather-compensated flow temperature control. These control systems (automatically) reduce the heating power in the rooms when the heat demand decreases, thus preventing an oversupply of heat (energy). The analysis of hourly and average indoor measurements was compared to outdoor temperatures (weather station in Cologne-Bonn, Station ID 02667). The analysis was limited to heating days, i.e., days where the average outdoor temperature does not exceed $15^{\circ} \mathrm{C}$, following VDI guideline 2067/DIN $4108 \mathrm{~T} 6$.

\section{(ii) Estimation of potential energy savings based on an optimized heating system}

The potential savings (in \%) were determined per office and calculated based on the integral of the temperature difference between the room temperature (actual or set temperature) and the outdoor temperature:

$$
\text { Saving Potential }(\%)=\frac{\int \uparrow=(\text { Set }- \text { Temperature }- \text { Outdoor Temperature })}{\int \uparrow(\text { Actual }- \text { Temperature }- \text { Outdoor Temperature })} * 100
$$

This analysis of potential savings is based on three scenarios (Table 4).

Table 4. Scenarios for temperature during and outside working hours.

\begin{tabular}{cl}
\hline Scenario 1 & No reduction in temperature. The room temperature is kept at a constant level of $21^{\circ} \mathrm{C}$. \\
\hline Scenario 2 & $\begin{array}{l}\text { A temperature of } 21^{\circ} \mathrm{C} \text { is maintained during working hours. Outside working hours and } \\
\text { at weekends, the temperature is reduced to } 17^{\circ} \mathrm{C} .\end{array}$ \\
\hline Scenario 3 & The temperature is reduced to $20^{\circ} \mathrm{C}$ during and $18^{\circ} \mathrm{C}$ outside working hours \\
\hline
\end{tabular}

The analysis does not consider energy consumption that could result from continuous ventilation and the inertia of the building. The storage capacity of the building prevents the temperatures from changing as quickly as the profile suggests, but the method still provides a good indicator of whether and how much energy could be saved by a time profile.

\subsubsection{Results on the Monitoring of the Existing Heating System}

The results demonstrate an interdependency of the room temperature and outside temperature for 10 offices $(\mathrm{N}=12)$. This means that rising outdoor temperature between the range of $-10{ }^{\circ} \mathrm{C}$ to $20^{\circ} \mathrm{C}$ leads to rising room temperatures. The Pearson correlations of both temperatures are in the medium to high range in 10 offices (see Figure 1 and its values in the upper left field).

In summary, all buildings have an oversupply of heating power when the outside temperature rises, regardless of whether it is a new (A, passive house) or an old building (B, C).

Two of 12 offices do not demonstrate an interdependency of the room temperature and outdoor temperature (Building B, C), but still there is an oversupply of heating power because these rooms are linked to the others via heating circuits.

Hence, the output of the heating system is not sufficiently reduced for all offices, which means that the room automation or the existing thermostatic valves are not working properly. Assumed reasons are, for example, the settings of the room thermostats are set to maximum levels; the thermostatic valves do not operate in the appropriate control range: A thermostatic valve set to level four attempts to reach a room temperature of $24^{\circ} \mathrm{C}$, the weather-compensated flow temperature control prevents this on colder days, but not when it gets warmer.

Finally, the analysis revealed that the heating system was not turned off in non-heating seasons (see datapoints at around $20^{\circ} \mathrm{C}$ outdoor temperature in Figure 1). 


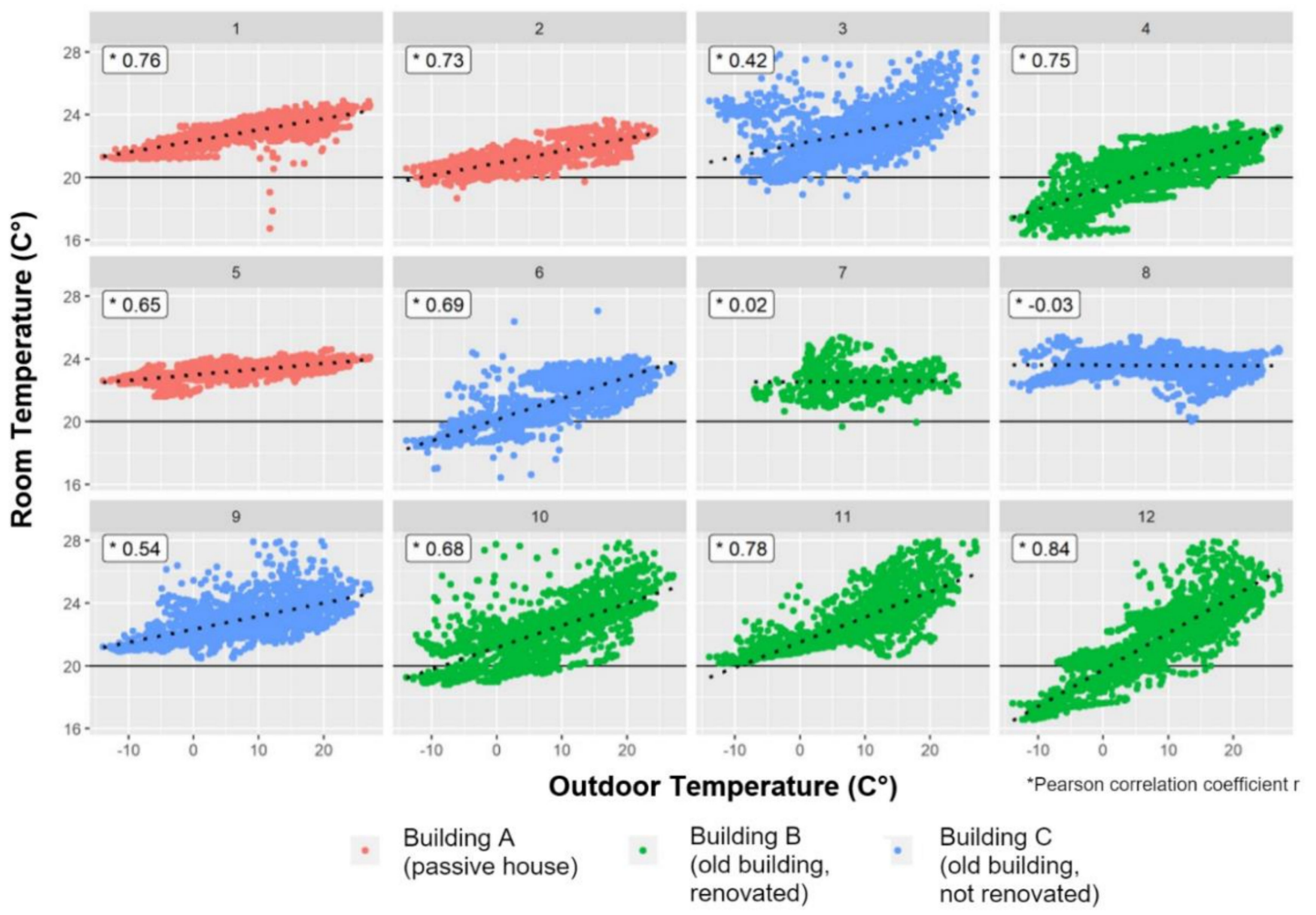

Figure 1. Results of temperature signatures in 12 offices (based on monitoring with Extech Data Logger; February until May 2018).

4.2.2. Results of the Estimation of Potential Energy Savings Based on a Smarter Heating System

Savings potentials were demonstrated for all three scenarios and depend on the scenario and building (Table 5). In scenario 1, the average potential of energy savings is estimated with 5-6\%; in scenario 2, with $9 \%$ (working hours) and $27 \%$ (non-working hours); and in scenario 3, with $16 \%$ (working hours) and 22\% (non-working hours) (see Table 5).

Table 5. Results on potential energy savings (in \%) based on lowering the temperature in three scenarios ( $\mathrm{N}=12$ Offices; WH: Working hours (9-16 h); NWH: Non-working hours e.g., at weekends).

\begin{tabular}{|c|c|c|c|c|c|c|}
\hline & \multicolumn{2}{|c|}{ Scenario 1} & \multicolumn{2}{|c|}{ Scenario 2} & \multicolumn{2}{|c|}{ Scenario 3} \\
\hline & $21^{\circ} \mathrm{C}(\mathrm{WH})$ & $21^{\circ} \mathrm{C}(\mathrm{NWH})$ & $21^{\circ} \mathrm{C}(\mathrm{WH})$ & $17^{\circ} \mathrm{C}(\mathrm{NWH})$ & $20^{\circ} \mathrm{C}(\mathrm{WH})$ & $18^{\circ} \mathrm{C}(\mathrm{NWH})$ \\
\hline $\begin{array}{c}\text { Building A } \\
\text { ( } \mathrm{N}=3 \text { offices) }\end{array}$ & & 7-9\% & $9 \%$ & $27 \%$ & $15 \%$ & $22 \%$ \\
\hline $\begin{array}{l}\text { Building B } \\
\text { ( } \mathrm{N}=5 \text { offices) }\end{array}$ & & $1-2 \%$ & $7 \%$ & $26 \%$ & $14 \%$ & $20 \%$ \\
\hline $\begin{array}{l}\text { Building } \mathrm{C} \\
\text { ( } \mathrm{N}=4 \text { offices })\end{array}$ & & $6-7 \%$ & $11 \%$ & $27-29 \%$ & $18 \%$ & $22-24 \%$ \\
\hline $\begin{array}{c}\text { Average } \\
(\mathrm{N}=12 \text { offices })\end{array}$ & & 5-6\% & $9 \%$ & $27 \%$ & $16 \%$ & $22 \%$ \\
\hline
\end{tabular}

In conclusion, the estimated energy savings range between $5-27 \%$ and can be achieved by adapting the system technology during and outside working hours. Accordingly, the efficiency of the heating system can be increased by a weather-dependent setting of the flow temperature control and by lowering the temperature levels outside working hours.

(iii) Results on potential energy savings based on the interviews and workshops

Based on expert interviews $(\mathrm{N}=19)$ and workshops $(\mathrm{N}=26)$ with office users and facility management, the estimation results on estimated energy savings were further assessed: 
The findings of the interviews and workshops show that realizing potential energy savings of up to $20 \%$ can be archived when applying a user-oriented approach of building management system (BMS). Thereby, the energy saving does not exclusively result from the ventilation behavior. In addition, the monitoring has shown that out of concern for restrictions in comfort, the use of night setback and weekend setback options has been made only very hesitantly. This estimation of savings potential was based on the calculation of degree days (temperature difference between inside and outside during the heating period). In particular, this means that an improved Building Management System (BMC) for energy efficiency, as estimated by lowering the temperature in offices, should be complemented with an interactive user perspective to identify faulty settings of the system technology (partly intentional), non-energy-efficient user behavior, and improve complaint-management between office users and facility management. Thereby, all different stakeholders of the building (office users, technical staff, facility management) must be part of the system that promotes communication, interaction, and feedback. In this context, the interviews and workshop results offered two main challenges and recommendations:

Challenge 1: The heating system is controlled in a way to seek maximum of comfort at workplace but with losses of energy efficiency. With this strategy of heat (over)supply the facility management aims to avoid complaints by office users (avoidance strategy); mainly steered by a minority of office users but significant because of their hierarchical position or due to their many complaints.

Recommendation 1: A system allowing for better communication between office users and facility management to align efficient system operations, energy savings, and comfort at the workplace. This can be enabled with shared real-time data on technical and environmental parameters (energy consumption, temperature, $\mathrm{CO}_{2}$ ) as well as user wellbeing (perceived comfort level of room climate). In consequence, the facility management does not receive situational complaints, but a full overview of the building's performance and user satisfaction to identify building sections with an oversupply of heat and influential factors (e.g., solar radiation).

Challenge 2: Although the office users' knowledge for energy efficiency strategies at the workplace was high, the implementation and acceptance of effective measures (lowering the temperature, changing ventilation practices) can be challenging.

Recommendation 2: Enabling active and early user participation when implementing energy efficiency strategies through interactive feedback systems. The systems should be developed with a design perspective and address both: User wellbeing (comfort temperatures) and motivational factors to help achieve self-set goals and to change ventilation practices.

\subsection{Experiment: Piaf-An Interactive System for Changing Ventilation Practices in Offices}

This section presents results of the prototyping, testing, and evaluation phase of the interactive feedback system Piaf (Phase 2-3-Steps 3-5). This includes (i) a description of the co-creation process and results on the overall acceptance of Piaf, including (ii) the experiment results to demonstrate to what extent office ventilation practices changed based on the interaction with Piaf.

\section{(i) Description of the co-creation process and results on the overall acceptance of Piaf}

The co-creation of the interactive feedback system (2016-2019) was conducted in three iterative steps, each with prototypes (Hangar, Piaf 1, Piaf 2; see Figure 2), embodying learnings and insights from the prior iteration. In the process, the teams of researchers, technical developers, and industrial designers collaborated with potential users. Thereby, the focus was both technical feasibility and addressing the overall acceptance of the prototypes (e.g., style, emotional product attachment, product usability). 


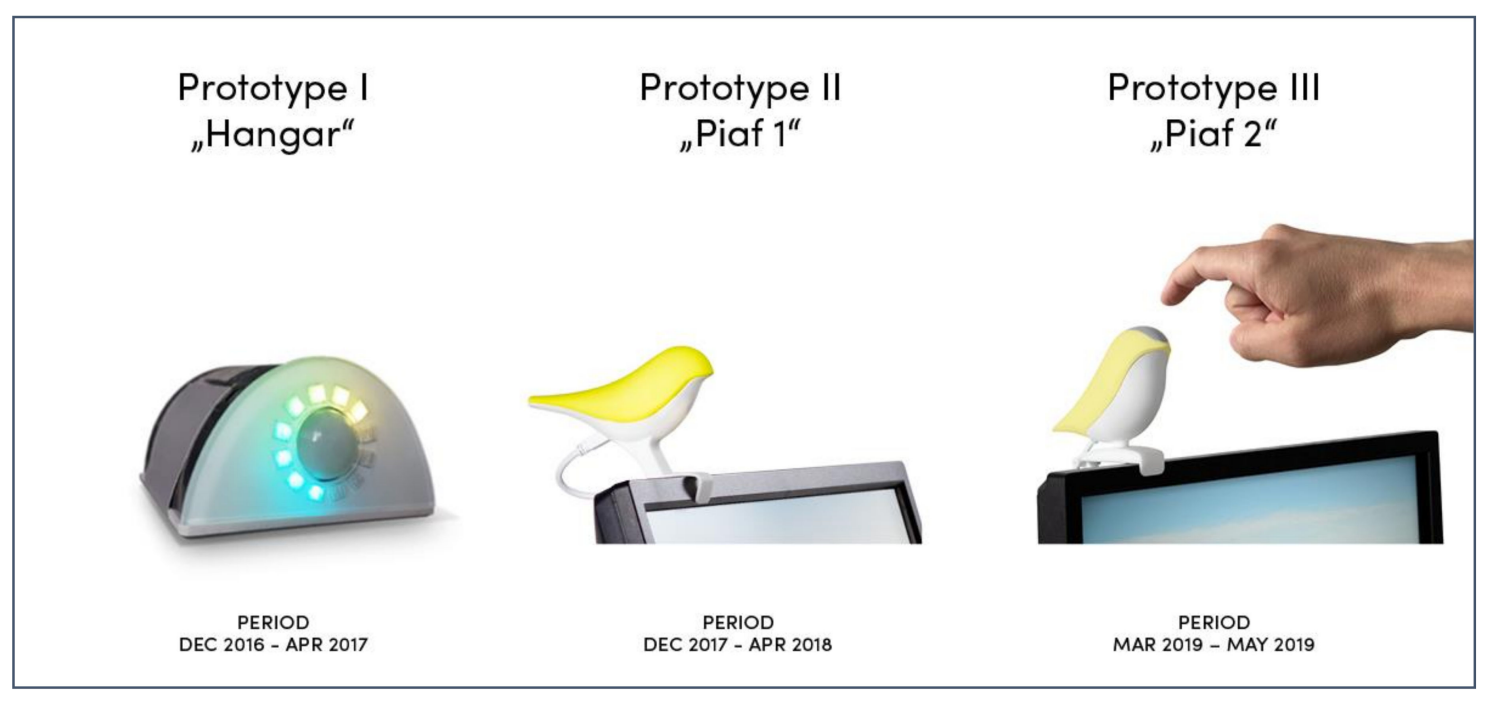

Figure 2. Overview of the three different prototypes (Image: EBZ Business School/twistid GmbH \& Co).

Prototype I ("HANGAR")—-developed by an engineering office—was built focusing exclusively on functionality and displaying a status. Prototype II ("PIAF" 1) and prototype III ("PIAF" 2) were developed by a design studio, involving user interaction, and focused on user interface (UI) understanding and emotional inclusion.

Prototype I ("HANGAR") included a plain, functional sensor casing and was built with a technical engineer's perspective. It offered a basic feedback on indoor air quality based on a circular LED matrix visualizing changes of temperature and $\mathrm{CO}_{2}$ concentration in the room. Based on tests with "HANGAR" in 16 offices in Bonn (December 2016-April 2017), the technical functioning of the sensors was evaluated positively. However, results also showed that future tests require a more human-centered and design-oriented prototype that improve the product acceptance and understanding. Accordingly, the next iterations and prototypes were conducted in collaboration with industrial designers who proposed changes in the concept, driven by a more human-centered approach. In addition, the feasibility for the production and the assembly of a small series of first 60 , then 100 , samples had to be considered.

As a result, Prototype II ("PIAF 1") was proposed by the industrial design team with the strategy to translate a user-centered research approach into a tangible story: The canary in the coal mine. The phrase refers to former practice of coal miners using birds as indicators and early warning of dangerous air conditions underground. Thus, PIAF is an interactive system fitted with logging capabilities $\left(\mathrm{CO}_{2}\right.$, temperature, air humidity) and in the shape of a bird allowing for personal room climate assistance by providing direct feedback on room air quality $\left(\mathrm{CO}_{2}\right.$ concentration). Piaf is no longer an anonymous technical device, but a personal assistant with a name, available in five different colors. The shape and the related meaning (narrative) communicates the technical idea of the smart airing assistant in an emotional way. It was presumed that this emotional narrative would lead to more interactions; thus, supporting changes in everyday ventilation practices.

PIAF 1 is enhanced with two different (visual and sound) signals calling the user to action. The visual signal suggests users to open the window (bad air quality) and the sound signals (chirping) suggest users to close the window (good air quality). Thereby, Piaf interacts with the users' attention to encourage energy efficient indoor climate and thus calls for changes in behavior and ventilation practices.

Piaf can be placed on the monitor at the user's workplace. The bird's belly faces towards the user and lights up via integrated RGB LED and depending on the air quality $\left(\mathrm{CO}_{2}\right)$. The five level colors range according to $\mathrm{CO}_{2}$ concentration and DIN EN 13779:2007-09. In addition, the LED pulsates and thus stylizes breathing e.g., a white and green color in combination with a slow pulse (calm breathing) signals good or very good air quality $(1200 \mathrm{ppm} \mathrm{CO} 2)$ and no ventilation is required (see Table 6). 
Furthermore, users (and facility management) can see PIAFS data logging results on a live data platform (see Figure 3).

Table 6. Characteristics of Piaf (Images: EBZ Business School 2019).

\begin{tabular}{|c|c|c|c|}
\hline Colour & Pulse and Sound Signal & Meaning & $\begin{array}{l}\mathrm{CO}_{2} \text { Concentration } \\
\text { (Approx. In ppm) }\end{array}$ \\
\hline & $\begin{array}{l}\text { Slow ( } 45 \text { s/pulse) } \\
\text { No sound }\end{array}$ & Air quality is very good-no need for action. & $750-1000$ ppm \\
\hline & $\begin{array}{l}\text { Medium ( } 35 \text { s/pulse) } \\
\text { No sound }\end{array}$ & Air quality is good-no need for action. & 1000-1200 ppm \\
\hline & $\begin{array}{l}\text { Fast }(27 \text { s/pulse }) \\
\text { No sound }\end{array}$ & Air quality is decreasing_-still no need for action. & $1200-1450$ ppm \\
\hline & $\begin{array}{l}\text { Very fast (16 s/pulse) } \\
\text { No sound }\end{array}$ & Air quality is bad-please open the window. & $>1450$ ppm \\
\hline & $\begin{array}{l}\text { Very slow ( } 60 \mathrm{~s} / \text { pulse }) \\
\text { Sound: chirping }\end{array}$ & $\begin{array}{l}\text { Air quality is good now, the room starts to cool } \\
\text { down-please close your window. }\end{array}$ & $<750 \mathrm{ppm}$ \\
\hline
\end{tabular}

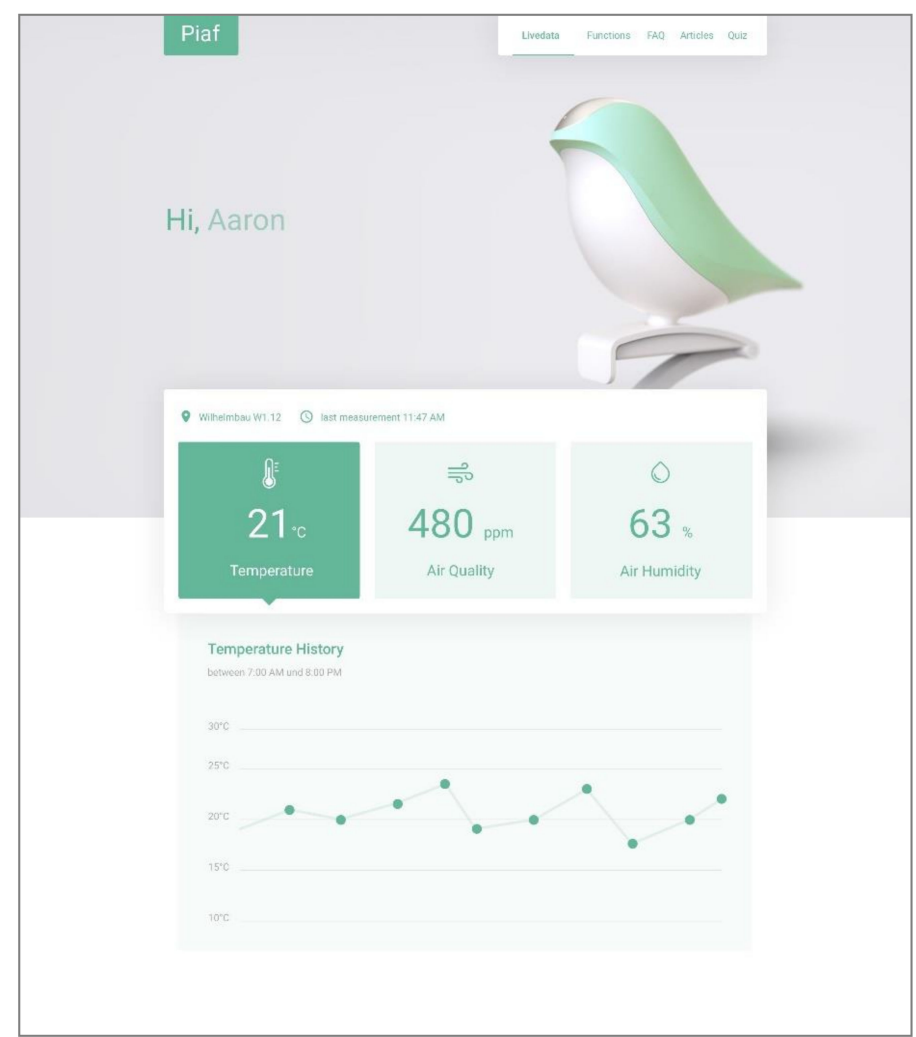

Figure 3. Screenshot of the Piaf online platform (Image: Handt and Wolber). 
Based on a co-creation workshop ( $\mathrm{N}=12$, Bochum) and internal discussions, different feedbacks were collected on the overall acceptance (style, usability, and meaning) of the design of PIAF 1. Based on the positive feedback, it was decided to continue to work with Piaf, to start an experiment with Piaf in offices in Bonn $(\mathrm{N}=45)$ and in Berlin $(\mathrm{N}=27$; see experiment results below).

After the experiment with PIAF 1 an anonymous online survey on the user experience (UX) was conducted with the participants $(\mathrm{N}=26$, Bonn). The survey focused on ergonomic and cognitive perception, overall acceptance, as well as their estimation on the usefulness of the airing assistant for improving ventilation practices. The results of the survey showed an overall acceptance of the prototype. For examples, participants stated that they would like to get an additional Piaf for their private home, to show and recommend the solutions to friends and family (exhibiting feeling of pride). However, the survey results also revealed opportunities for improvements. Apart from technical improvements, two essential modifications have been made, based on the user feedback:

- The sound signal indicating to close the window was prolonged and amplified, to increase sound interference with users.

- A confirmation button was integrated, developed to check if modified airing practice is tied to Piaf. In addition, the capacitive switch, integrated as a confirmation button, offered additional sensual involvement, and reinforced user interaction and emotional attachment.

Prototype III ("PIAF 2") is a derivative of PIAF 1, but enriched with bidirectional feedback capabilities, inviting users to confirm their action. This was an essential evolution for proving whether changes in ventilation practice are tied to intervention with PIAF.

In conclusion, the co-prototyping demonstrates the success and advantage of the iterative and human-centered design approach, because it allows for precise monitoring of evolutions, corrections, and adaptations of the system, by identifying problems and failures, as well as evaluating the need as well as the expendability of particular features in the prototypes.

\section{(ii) Experiment results on the ventilation practices the with Piaf 1 in Berlin}

The ventilation practices were observed in 34 different offices in Berlin and over two heating periods in 2018 and 2019. This included 27 offices equipped with Piaf 1 (Prototype II) and 12 offices without Piaf (see Table 7). The rooms are individual offices and the $\mathrm{CO}_{2}$ measurements indicate regular use of the offices (during normal working hours). The offices of the building A face towards north, an inner courtyard, and to the south but without sunlight due to other blocking buildings. The offices of building $B$ are directed to the north and the offices of building $C$ are directed to south-west.

Table 7. Overview of the participated offices in the Piaf experiment (two heating periods in 2018 and 2019).

\begin{tabular}{|c|c|c|}
\hline & $\begin{array}{c}\text { Interaction with Piaf } \\
\text { (Collected Data Based on Piaf Sensors) }\end{array}$ & $\begin{array}{c}\text { No Interaction with Piaf } \\
\text { (Collected Data Based on Extech Sensors) }\end{array}$ \\
\hline Heating period & December 2018-April 2019 & February 2018-May 2018 \\
\hline $\begin{array}{l}\text { Offices in Building A } \\
\text { Passive house standard }\end{array}$ & 9 & 3 \\
\hline $\begin{array}{l}\text { Offices in Building B } \\
\text { Old building (renovated) }\end{array}$ & - & 5 \\
\hline $\begin{array}{l}\text { Offices in Building C } \\
\text { Old building (not renovated) }\end{array}$ & 18 & 4 \\
\hline Total offices & 27 & 12 \\
\hline
\end{tabular}

Furthermore, the Piaf system was tested in two different building types:

1. Old building: The Piaf system was tested in an old, not renovated building and without ventilation systems. This building was selected because retrofitting a ventilation system involves high installation effort and is therefore hardly ever carried out. The approach with Piaf works with a minimum of intervention in the building services engineering. 
2. Building with passive house standard: Piaf was also tested in a building with passive house standard because previous studies have shown that passive houses have problems in archiving target values for energy consumption, mainly due to user behavior. While in the case of single-family houses, the builders have consciously chosen a passive house with controlled ventilation, this is not the case with office buildings. Indeed, the window should not be opened here either. However, in the investigated building, the users insisted on retrofitting window handles, as the air was subjectively perceived as too bad. Thus, the experiments were deliberately carried out in the passive house to visualize and feedback to the users that the air quality is normally good and that there is no need to open the window. Furthermore, the data recorded by Piaf can generally be used to determine whether rooms are over or undersupplied and, if appropriately networked, to ensure that operations are managed according to requirements.

The data on ventilation practices (e.g., air quality in $\mathrm{CO}_{2}$, ppm) were collected with sensor technology, either included in Piaf or supported in offices without Piaf by Extech technology (see Table 7). The data collected were not fed into the building automation system, but this is certainly intended for future projects.

Based on the collected data an algorithm was developed, which enabled the identification of the ventilation practices. This analysis focused on (changes) of the $\mathrm{CO}_{2}$ levels during the ventilation practice. Furthermore, the analysis did not consider data if outside temperature exceeded $15^{\circ} \mathrm{C}$.

In total, 1.271 ventilation practices were identified including 1.039 ventilation practices based on 27 offices with Piaf sensors and 232 ventilation practices based on 12 offices without Piaf (Extech sensors).

For better understanding of what data were collected with Piaf, Figure 4 illustrates exemplary results of Piaf based on one office and two days. It summarizes both the time- $\mathrm{CO}_{2}$-curve (top) and the time-temperature curve (bottom). Furthermore, it illustrates Piaf's thresholds for the visual (red, yellow, green, white, blue) and sound signal feedbacks.

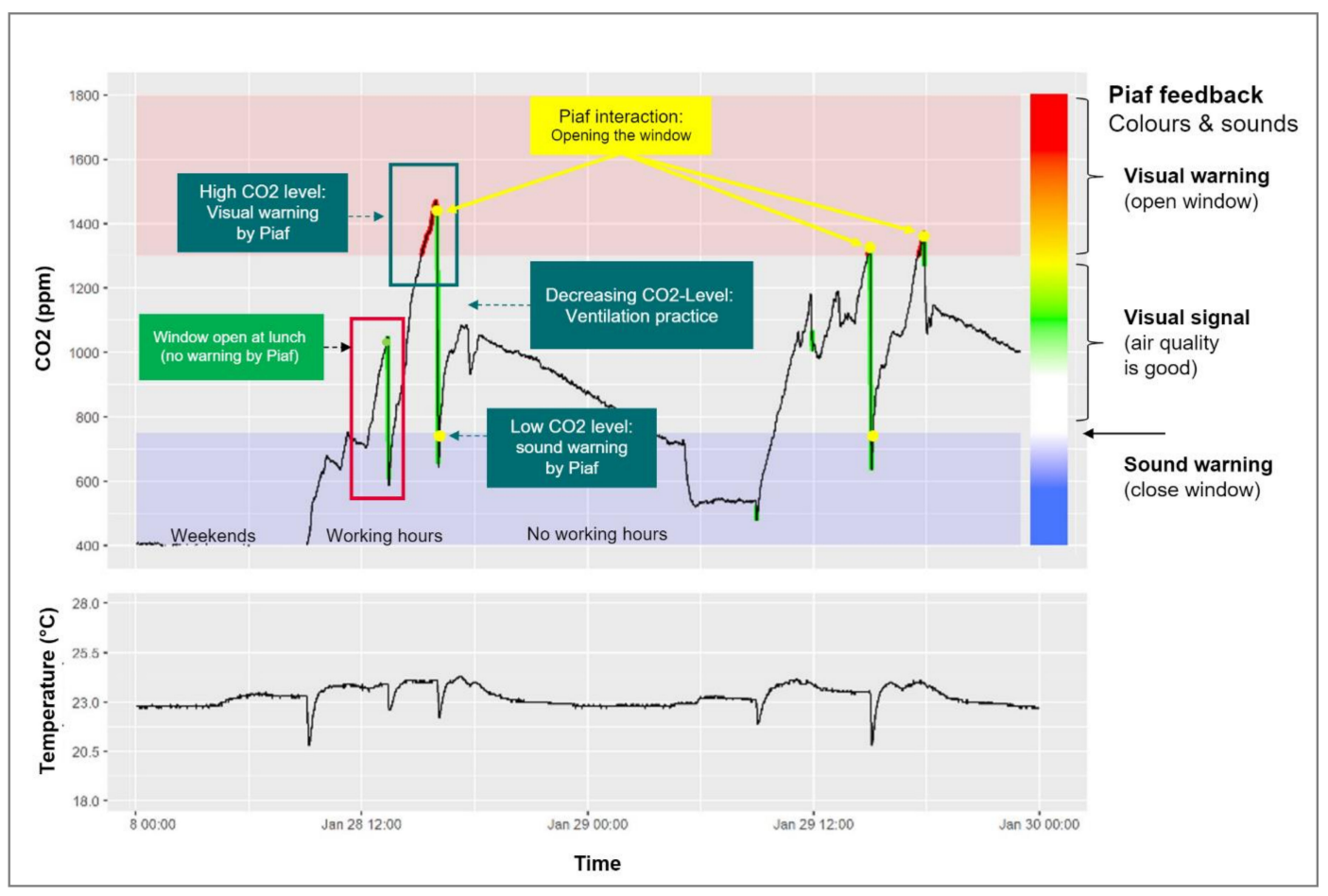

Figure 4. Interacting with Piaf in one office and over two days (yellow dots: Ventilation practices (opening/closing the window) based on the Piaf signal. Green dots: Ventilation practices outside of the warning zone). 
The following interpretation can be made for the results of the example above: At weekends, the office is not used, so temperature is stable $\left(\sim 23^{\circ} \mathrm{C}\right)$ and $\mathrm{CO}_{2}$ concentration falls to a very low level ( $\sim 400 \mathrm{ppm})$. On Monday morning, the office user starts working with a strong ventilation practice. This can be seen in the brief drop in room temperature from approximately $23^{\circ} \mathrm{C}$ to $20^{\circ} \mathrm{C}$. The $\mathrm{CO}_{2}$ concentration increases slowly.

At lunch, the office user opens the window for ventilation although there is good air quality ( 1000 ppm) and no warning by Piaf because the waring threshold of $1300 \mathrm{ppm}$ was not reached. In the afternoon, the $\mathrm{CO}_{2}$ concentration rises to $\sim 1500 \mathrm{ppm}$. At this level, Piaf interacts with the user through a visual warning signal (red coloration a high "breathing rate"). As a result, the user opens the window and starts the ventilation process. The $\mathrm{CO}_{2}$ level thus drops, combined with a significant drop in the room temperature. After falling below, the threshold $(<700 \mathrm{ppm})$ Piaf sound warning (chirping) starts, the office users close the window, and the $\mathrm{CO}_{2}$ concentration increases again.

In total, the results of the experiment show that the users accept the assistance system Piaf and encourages them to more needs-based ventilation practices. The interaction with Piaf leads to changes of the ventilation practices (see Figure 5) in both directions and thus can provide more comfort at the workplace. Furthermore, the experiment demonstrated the potential of Piaf to lower energy input: There is a reduction in the high $\mathrm{CO}_{2}$ concentrations (where ventilation was previously carried out much too late: $>1450 \mathrm{ppm}$ ) and a reduction in the low $\mathrm{CO}_{2}$ concentrations (where ventilation was previously carried out too early: $750-1000 \mathrm{ppm}$ ). This contributes to ventilation practices that are carried out according to needs. However, the tests with Piaf also demonstrated that the interactive design of Piaf (color and sound signals) is crucial to effectively guide users towards energy-efficient ventilation practices. There is the risk that Piaf's signals can encourage users to open the window (more often); but do not encourage users to close the window again based on its unobtrusive "closing signals" (chirping). This may improve air quality but also increase ventilation heat losses, hence energy use. Against this background, a new version of Piaf (Prototype II) would include a more "aggressive" chirping sound signal to make users aware to close the window again. However, interviews with the users also showed that stricter (patronizing) feedbacks can lead to limited acceptance, thus limited changes of the ventilation practices.

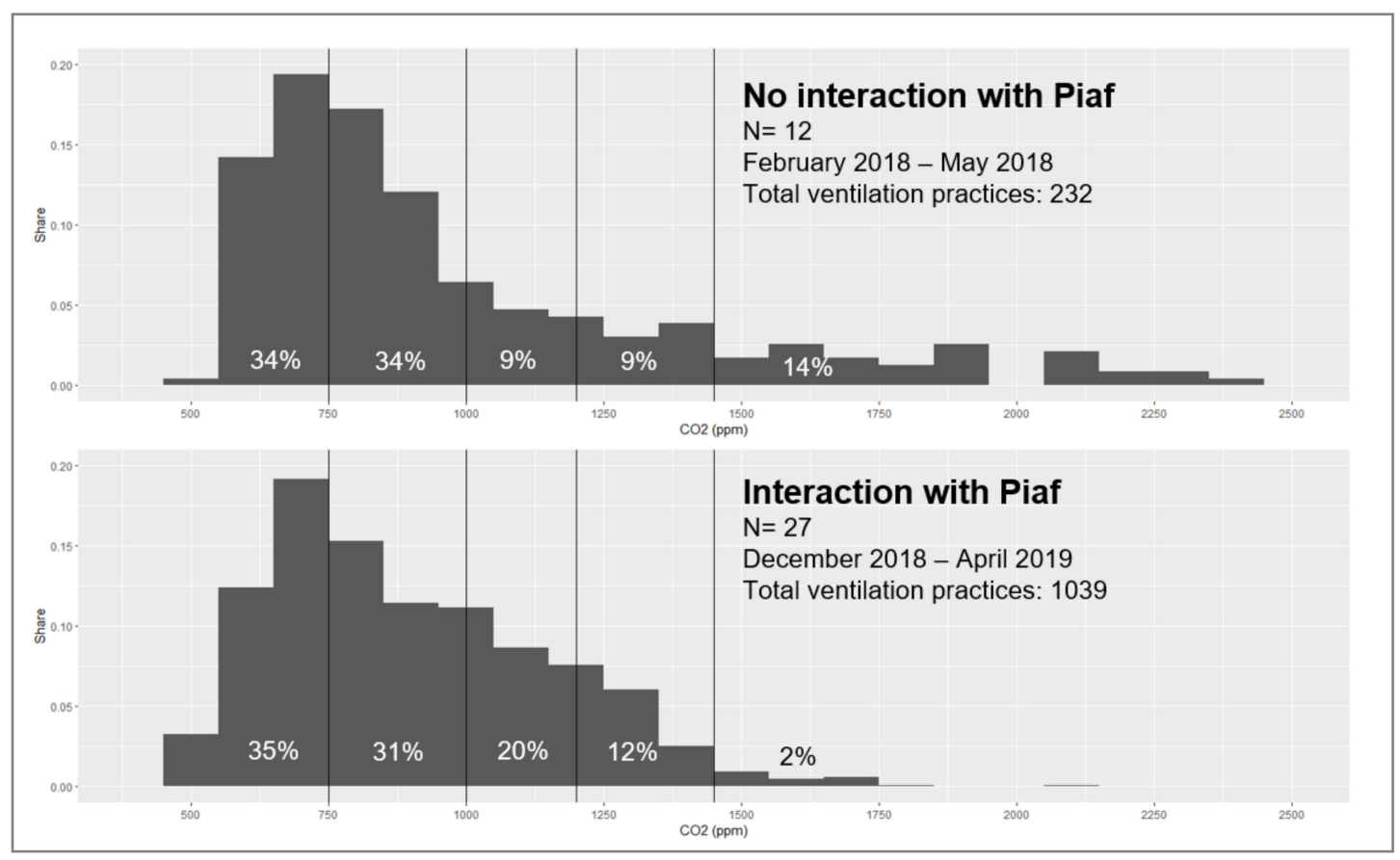

Figure 5. Overview of the ventilation practices with Piaf and without Piaf (data collected with Piaf and Extech sensors). 
In addition, the experiment demonstrated that the feedback including floating colors and non-strict commands can make users start a ventilation practice earlier (yellow/orange range).

Furthermore, the results highlight that ventilation practices continue to exist during conditions of already good air quality in the office room (below $750 \mathrm{ppm}$ : $34 \%$ vs. 35\%). These findings can be the result of established daily office routines as users initially start the ventilation practices in the morning when arriving in the office room. At this time, the interaction with Piaf may not even have been started because the office users open the window right after entering the room, before sitting at the desktop and looking at Piaf.

Other findings are the following:

- For one office (building C) it became visible that the suggestions of Piaf were followed at the beginning (5-6 weeks), but later "ignored" as observed $\mathrm{CO}_{2}$ levels increased. This could indicate a beginning of disinterest after initial enthusiasm for the system (Figure 6).

- For one office the introduction of Piaf did not significantly impact the ventilation practices. This might be because the natural office ventilation of the passive house (Building A) did not require additional ventilation practices. The $\mathrm{CO}_{2}$ concentration remains constant below $900 \mathrm{ppm}$, except for a few outliers (see Figure 7).

- The analysis of changing ventilations practices based on data from sensors offer findings on the starting point of the ventilation practice (decreasing $\mathrm{CO}_{2}$ levels). However, the collected data make it difficult to identify the stopping point of the ventilation practice. This means results on the duration of the ventilation were limited. Future research can improve the experiment design e.g., with sensors in the window to identify opening and closing of the window or by utilizing tracer gases to determine the air exchange rate in the room building (tracer-gas leak testing).

- The mounting of Piaf was designed for monitors at the workplace. However, the waste heat of (older) monitors confused the sensors of Piaf, making ventilation recommendations difficult.

- Direct sun light on Piaf can also bias the results (temperature and humidity).

- The experiment requires full WLAN connection ( $24 \mathrm{~h}, 7$ days a week) in all participated offices. Otherwise, collected data cannot be stored and analyzed.

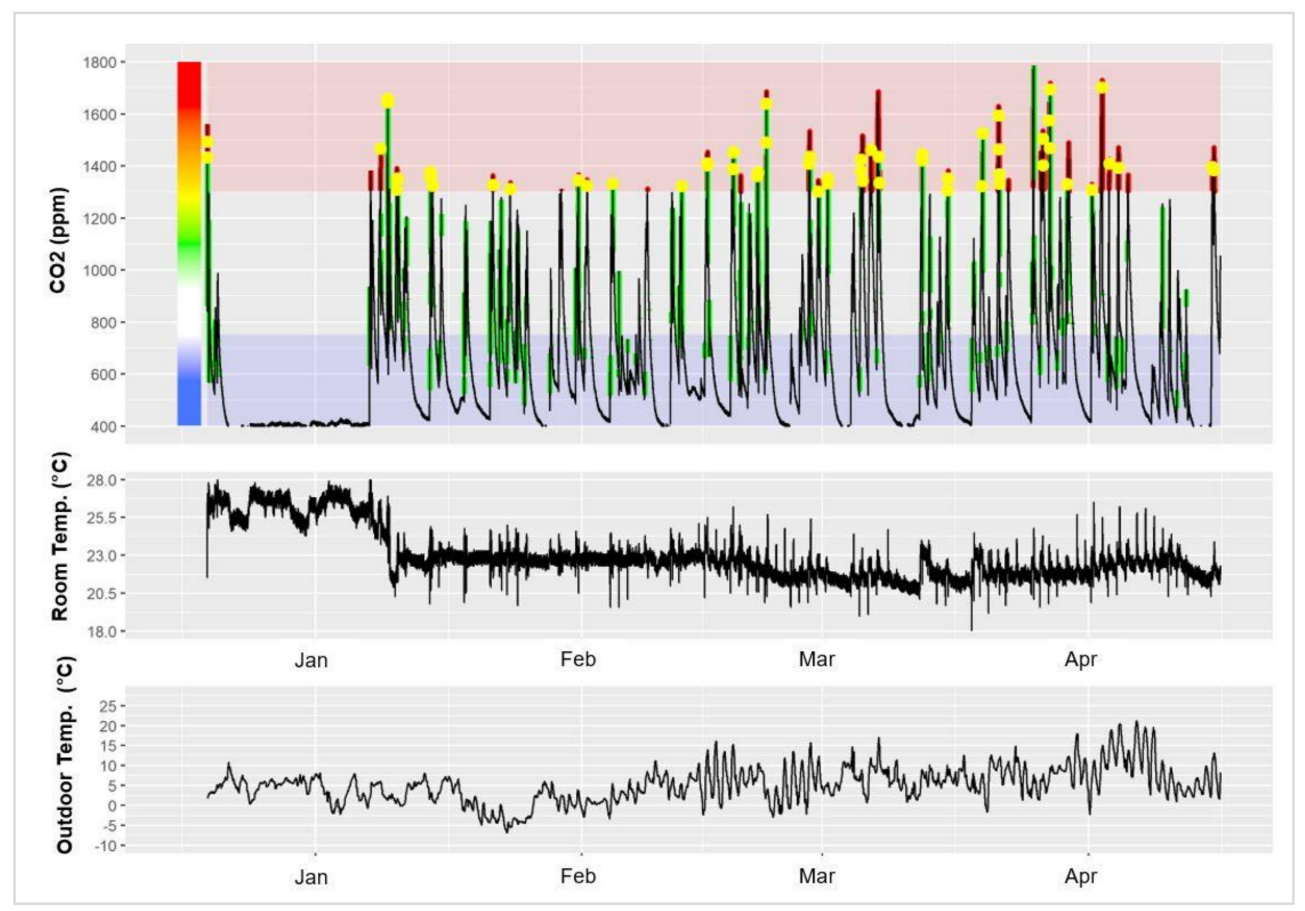

Figure 6. Overview of temperature and $\mathrm{CO}_{2}$ values (Building $\mathrm{C}$ ). 


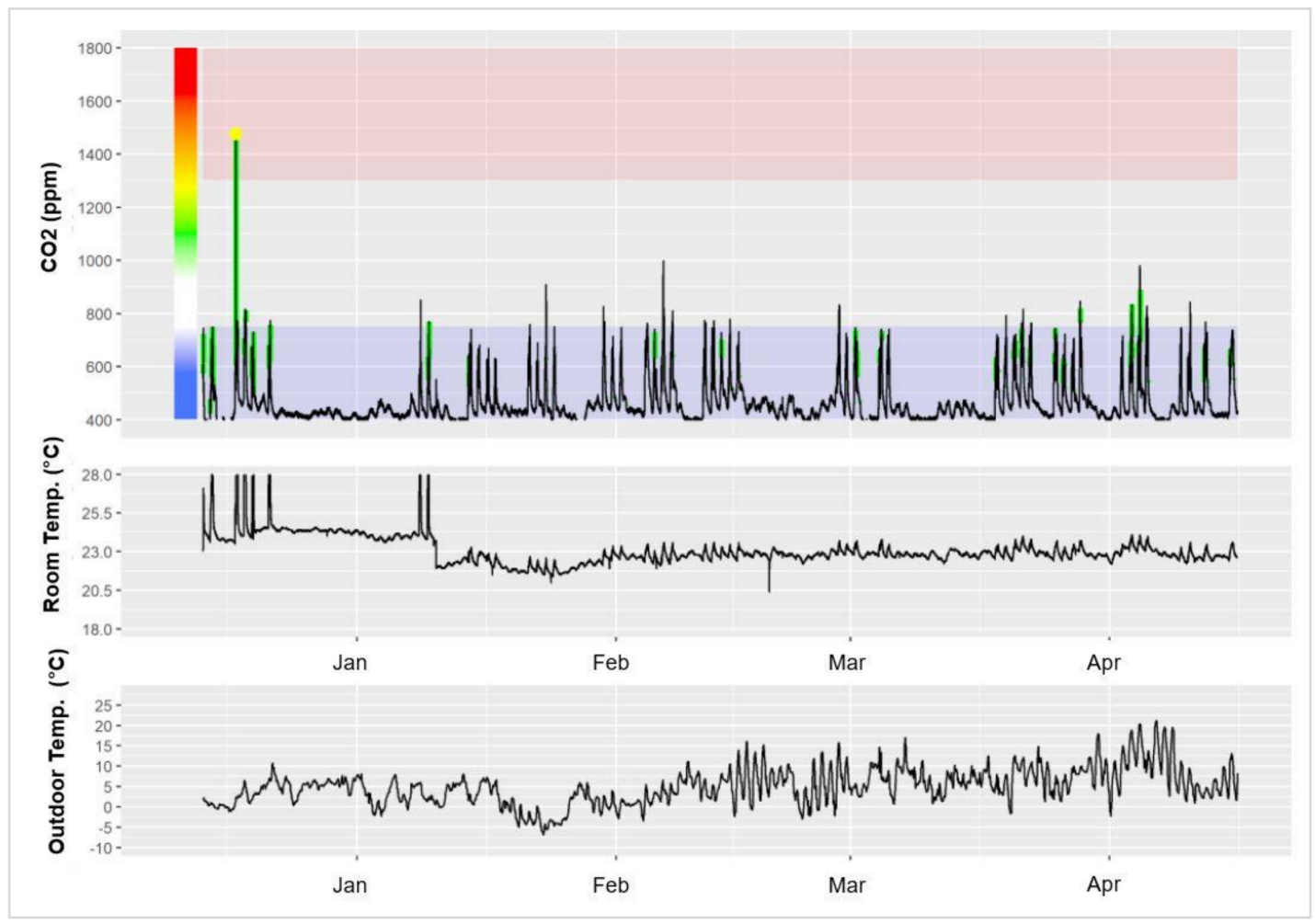

Figure 7. Overview of temperature and $\mathrm{CO} 2$ values (Building A; passive house standard).

In summary, the findings of Piaf demonstrate that interactive systems can positively encourage behavior change and Piaf can represent an essential element of a user-centered building management system (UC-BMS). Furthermore, effectively supporting behavior change requires engaging systems including meaningful design that elicits positive emotional attachment in users as demonstrated with the tangible story (narrative) of the canary in the coal mine. However, results have also been shown that for some users, and after initial enthusiasm for the system, the motivation to interact with Piaf can also decrease over time.

\subsection{Room Climate Comfort Check}

This section summarizes the results of the survey "Comfort Check" that focuses on the felt comfort level of temperature in the office (see Figure A1; Appendix A). Furthermore, the survey offered insights into functionality and acceptance for a digital platform enabling communication between facility management and office users (Phase 3-Step 5).

The survey results show that the perception of temperature can depend on different building characteristics: In buildings A and B, around $20 \%$ of the votes and only $9 \%$ in building C perceived the room temperature as "too warm" (Table 8). This difference can be explained by sunlight radiation (at building $\mathrm{A}$ and $\mathrm{B}$ ) and building properties (building $\mathrm{C}$ is an old building).

Table 8. Result of the room climate comfort survey ( $\mathrm{N}=24$ offices; daily/ 4 weeks, March-April 2018).

\begin{tabular}{ccccccc}
\hline Buildings & Much Too Cold & Too Cold & Just Right & Too Warm & Much Too Warm & Total Voting \\
\hline Building A & - & $3 \%$ & $75 \%$ & $20 \%$ & $2 \%$ & 314 \\
Building B & - & $6 \%$ & $73 \%$ & $21 \%$ & - & $(100 \%)$ \\
Building C & $>0.1 \%$ & $4 \%$ & $87 \%$ & $9 \%$ & - & $\begin{array}{c}\mathrm{N}=896 \\
(100 \%)\end{array}$ \\
\hline
\end{tabular}


Against this background, the survey illustrates opportunities to enable live feedback on perceived room temperature and thus can support identification of further energy-saving potentials, for example the heating power in building A and B could be reduced. In addition, such a survey can help to avoid unnecessary complaints about room temperature.

Findings from interviews with facility management suggest a survey (Comfort-Check) that can enable better communications between facility management and office users. In this way, the operation and performance of the heating system can be adapted towards the actual needs of the office users and not towards a few opinion leaders. However, depending on the heating circuit in the building, adaptions can be made for sections in the building only.

Results on the functionality and acceptance of the daily survey showed positive outcomes. The survey participants did not perceive the daily email traffic as disturbing for several reasons: (i) Rewarding: The survey participation was optional but rewarded by an organic soup box, if all 40 votes were completed; the survey was communicated as "Soup Challenge"; (ii) appealing design and appropriate scheduling: The survey was developed in collaboration with a design agency; (iii) transparency and competition: An online platform allowed participants to check their own results and to compare the results with other participants (working colleagues) (see Figure A2; Appendix A).

\section{Conclusions}

\subsection{Summary}

Based on a living lab study on interactive design to encourage energy efficiency in offices, this paper demonstrates how coercive (automation) and reflective (behavioral-oriented) design interventions can save up to $20 \%$ energy in office buildings while maintaining or even improving comfort and work productivity.

The results indicate that utilizing energy saving potentials requires a system approach, a user-centered building management system (UC-BMS) that interlinks the technical and user (design) perspective and various stakeholders of the building (office user, technical staff, facility management, building operators). This reveals the dependencies of specific building characteristics, indoor climate, the individual user behavior, system technology, and its operations made by facility management. Against this background, this paper presented results on three main intervention levels and elements of UC-BMS (see Figure 8):

1. Central system optimization due to weather-dependent settings of the flow temperature control and by lowering the temperature levels outside (and during) working hours. Based on an estimation including 12 offices and three scenarios, the results indicate energy savings of $5-27 \%$. Thereby, the facility management should be supported in the system operations to maximize comfort and energy efficiency as well as to minimize complaints by office users. Accordingly, the literature review, interviews, and workshops have shown that realizing the full potential of energy savings require a user-oriented approach; otherwise, interventions may not be accepted.

2. Against this outcome, a user-oriented and interactive assistant system (called Piaf) was co-prototyped and tested to show to what extent daily routines of ventilation practices at the workplace can be changed. The experiment results of Piaf $(\mathrm{N}=27)$ indicate three main insights: First, there are positive effects of Piaf encouraging behavior change (ventilation practices). Second, effectively supporting behavior change requires engaging systems with a meaningful design that can elicit positive emotional product attachment. In this way, Piaf was designed based on a tangible story titled "the canary in the coal mine". Feedback systems are thus no longer an anonymous technical device, but a personal assistant with a personality. Third, sharing Piaf's climate data of each office room with facility management can support the operations for an optimized central system and the development of a digital communication platform.

3. A survey on the individual comfort level of temperature in offices ("Comfort Check"; $N=24$ ) provided insights on how to expand a digital communication platform between facility 
management and office users. The results made it clear that the perception of temperature has building-specific characteristics, that live feedback can localize further energy-saving potentials, and can help to limit complaints and to adapt the heating system towards actual user needs and not a few "opinion leaders". Nevertheless, depending on the building heating circuit, adaptions can made for building sections only.

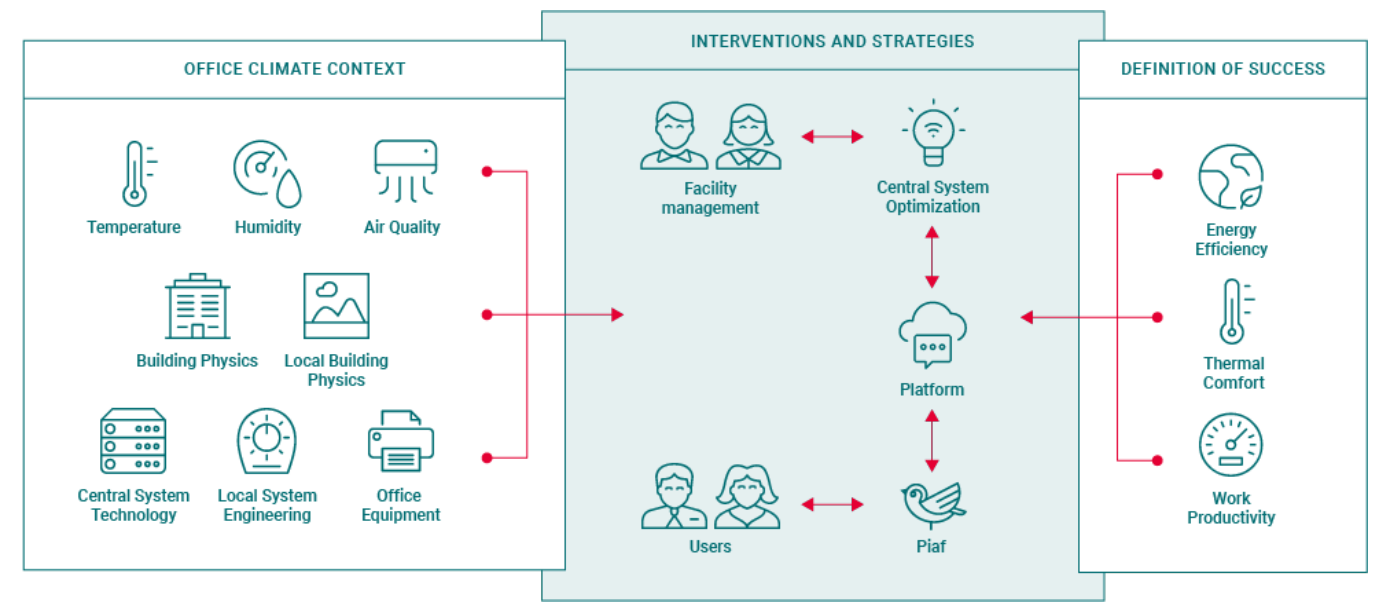

Figure 8. Overview of the user-centered building management system (UC-BMS).

\subsection{Future Research}

Based on living lab research and further dynamic, longitudinal studies regarding user perception of interactive systems (e.g., Piaf) could further emphasize the overall 'shape' of change rather than single points in time (e.g., first impression). This could include the exploration of motivational journeys of users and if new practices (energy efficient ventilation) still become daily routines even though the interactive systems are not in use after initial interest. In addition, the duration of the ventilation could be further explored based on tracer-gas leak testing. Furthermore, future research can explore Piaf's effects on the acceptance of other (automated) energy efficiency strategies, for example lowering the temperature in offices.

Though the tested user-centered energy efficiency strategy seems to be useful for user wellbeing, many other factors determine satisfaction at the workplace, for example, office furniture, light, and factors such as leadership models. Thus, future studies on energy efficiency could be linked to experiments including a broader perspective on wellbeing at the workplace and its implications on work productivity e.g., based on experience design and design for wellbeing approaches [54].

Furthermore, co-creation and development could focus on improving UC-BMS as a digital communication platform by enabling cloud technologies to allow for efficiency measures and the processing of all data such as heating system performance, room climate, and ventilation and heating behavior.

Finally, transferability of UC-BMS could be explored as part of a broader application to other office buildings and contexts, for example with systematic guidelines for different types of buildings, heterogeneity of users (values, attitudes, norms), and climate zones. Furthermore, a business model could be explored as part of a long-term energy efficiency strategy and contribution to climate-neutral offices buildings.

Author Contributions: Conceptualization: C.B., V.G., K.L., B.K., J.P., and P.T.; data curation: K.L.; formal analyses: C.B., K.L., B.K., J.P., and P.T.; investigation: C.B., V.G., K.L., B.K., J.P., and P.T.; methodology: C.B., V.G., K.L., B.K., J.P., P.T., and C.Z.; project administration: C.B. and V.G.; resources: C.B. and V.G.; software: B.K.; validation: C.B., V.G., K.L., B.K., J.P., and P.T.; visualization: B.K., J.P., and C.Z.; writing original draft: C.B., J.P., and P.T.; writing review-editing: C.B., J.P., V.G., K.L., B.K., J.V.G. and P.T. All authors have read and agree to the published version of the manuscript. 
Funding: This research was funded by the German Ministry of Economic Affairs, Innovation, Digitalisation and Energy of the State of North Rhine-Westphalia and Financed by the German Federal Institute for Building-, Urban- and Spatial Research, Grant Number: 10.08.17.7-17.15, W043A.

Acknowledgments: The authors are grateful to all the people who provided important information during the informal discussion and to Jonathan Handt and Aaron Wolber, who supervised the design of the project.

Conflicts of Interest: The authors declare no conflict of interest.

\section{Appendix A}

far too hot

rather warm

just right

rather cold

\section{far too cold}

Vote twice a day on how you feel about the temperature in your office. Stay tuned and win an organic soupbox from Little Lunch. You can check the interim results of your Soup Challenge here anytime. If you have any questions, feel free to contact us by e-mail: eeoffice@handtwolber.de.

Figure A1. Screenshot of the survey "Comfort Check" (Image: Handt \& Wolber). 


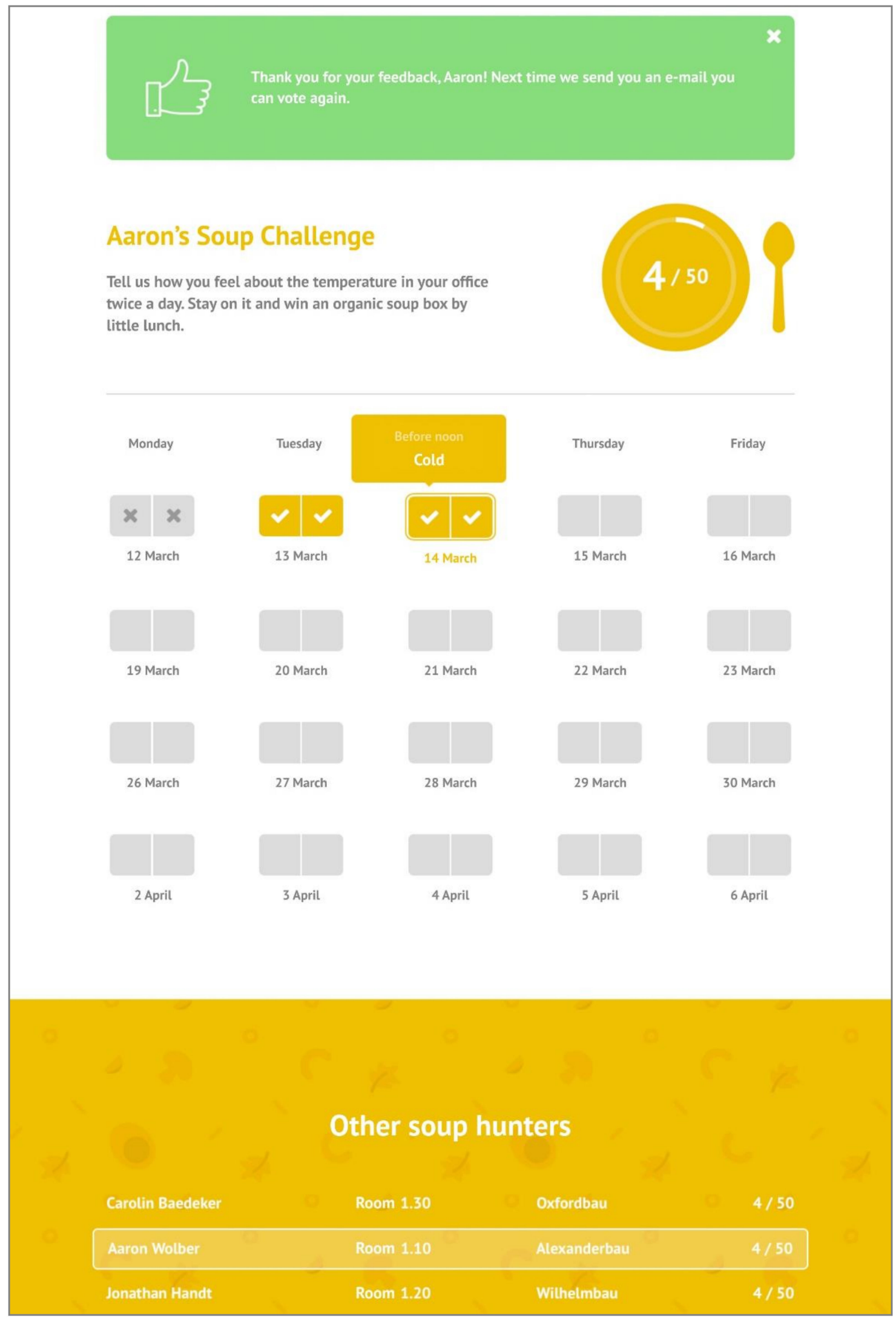

Figure A2. Screenshot of the survey "Comfort Check" (Image: Handt \& Wolber). 


\section{References}

1. IPCC. Climate Change 2014 Mitigation of Climate Change Working Group III Contribution to the Fifth Assessment Report of the Intergovernmental Panel on Climate Change; Edenhofer, O., Pichs-Madruga, R., Sokona, Y., Farahani, E., Kadner, S., Seyboth, K., Adler, A., Baum, I., Brunner, S., Eickemeier, P., et al., Eds.; Cambridge University Press: Cambridge, UK; New York, NY, USA, 2014.

2. Koirala, B.; Bohara, A.; Li, H. Effects of energy-efficiency building codes in the energy savings and emissions of carbon dioxide. Environ. Econ. Policy Stud. 2013, 15, 271-290. [CrossRef]

3. Laustsen, J. Energy Efficiency Requirements in Building Codes. In Energy Efficiency Policies for New Buildings; IEA Information Paper; International Energy Agency (IEA), Head of Communication and Information Office: Paris, France, 2008.

4. Robinson, J.F.; Foxon, T.J.; Taylor, P.G. Performance gap analysis case study of a non-domestic building. Proc. Inst. Civ. Eng. Eng. Sustain. 2016, 169, 31-38. [CrossRef]

5. Norford, L.K.; Socolow, R.H.; Hsieh, E.S.; Spadaro, G.V. Two-to-one discrepancy between measured and predicted performance of a "low-energy" office building: Insights from a reconciliation based on the DOE-2 model. Energy Build. 1994, 21, 121-131. [CrossRef]

6. Blight, T.S.; Coley, D.A. Sensitivity Analysis of the Effect of Occupant Behaviour on the Energy Consumption of Passive House Dwellings. Energy Build. 2013, 66, 349-355. [CrossRef]

7. Branco, G.; Lachal, B.; Gallinelli, P.; Weber, W. Predicted versus observed heat consumption of a low energy multifamily complex in Switzerland based on long-term experimental data. Energy Build. 2004, 36, 543-555. [CrossRef]

8. Thomsen, J.; Berker, T.; Lappegard, Å.; Hauge, K.; Solvår, D.; Jerkø, W.S. The interaction between building and users in passive and zero energy housing and offices: The role of interfaces, knowledge and user commitment. Smart Sustain. Built Environ. 2013, 2, 43-59. [CrossRef]

9. Gustafsson, A.; Gyllenswrd, M. The Power-Aware Cord: Energy Awareness through Ambient Information Display. In EA of CHI'05; ACM: New York, NY, USA, 2005; pp. 1423-1426.

10. Broms, L.; Katzeff, C.; Bång, M.; Nyblom, Å.; Ilstedt Hjelm, S.; Ehrnberger, K. Coffee maker patterns and the design of energy feedback artefacts. In Proceedings of the 8th ACM Conference on Designing Interactive Systems; ACM: New York, NY, USA, 2010; pp. 93-102.

11. Jensen, T.; Holtz, G.; Baedeker, C.; Chappin, E. Energy-efficiency impacts of an airquality feedback device in residential buildings: An agent-based modelling assessment. Energy Build. 2016, 116, 151-163. [CrossRef]

12. Jensen, T.; Holtz, G.; Chappin, É. Agent based assessment framework for behavior-changing feedback devices: Spreading of devices and heating behavior. Technol. Forecast. Soc. Chang. 2015, 98, 105-119. [CrossRef]

13. Grinewitschus, V.; Lovric, T.; Lacombe, J.; Beblek, A. Assisting user airing behaviour for saving energy. In Proceedings of the 8th International Conference on Energy Efficiency in Domestic Appliances and Lighting, 26-28 August 2015.

14. Buhl, J.; Greiff, K.; Baedeker, C.; Liedtke, C. Analysing Social Milieus and Lifestyles -Their Contribution to a Better Understanding of Heating Practices. Living Labs_Design and Assessment of Sustainable Living; Keyson, D., Guerra-Santin, O., Lockton, D., Eds.; Springer: Cham, Switzerland, 2016; pp. 247-257.

15. Lan, L.; Liab, Z.; Pan, L. The effects of air temperature on office workers' well-being, workload and productivity-evaluated with subjective ratings. Appl. Ergon. 2010, 42, 29-36. [CrossRef]

16. Buchanan, K.; Russo, R.; Anderson, B. Feeding back about eco-feedback: How do consumers use and respond to energy monitors? Energy Policy 2014, 73, 138-146. [CrossRef]

17. Buchanan, K.; Russo, R.; Anderson, B. The question of reduction: The problem(s) with feedback. Energy Policy. 2015, 77, 89-96. [CrossRef]

18. Meier, A.; Aragon, C.; Hurwitz, B.; Mujumdar, D.; Perry, D.; Pfeffer, T.; Pritoni, M. How people actually use thermostats. In ACEEE Summer Study on Energy Efficiency in Buildings; ACEEE: Washington, DC, USA, 2010.

19. Schwartz, T.; Stevens, G.; Jakobi, T.; Denef, S.; Ramirez, L.; Wulf, V.; Randall, D. What People Do with Consumption Feedback. A Long-Term Living Lab Study of a Home Energy Management System. Interact. Comput. 2015, 27, 551-576. [CrossRef]

20. Strengers, Y. Designing Eco-Feedback Systems for Everyday Life. In Proceedings of the 2011 Annual Conference on Human Factors in Computing Systems, Vancouver, BC, Canada, 7-12 May 2011.

21. Brehm, J.W. Theory of Psychological Reactance; Academic Press: New York, NY, USA, 1966. 
22. Laschke, M.; Diefenbach, S.; Hassenzahl, M. "Annoying, but in a nice way": An inquiry into the experience of frictional feedback. Int. J. Des. 2015, 9, 129-140.

23. Diefenbach, S.; Kapsner, A.; Laschke, M.; Niess, J.; Ullrich, D. Technology for Behavior Change-Potential, Challenges, and Ethical Questions. J. Interact. Media 2016, 15, 195-201. [CrossRef]

24. Buhl, J.; Hasselkuß, M.; Suski, P.; Berg, H. Automating Behavior? An Experimental Living Lab Study on the Effect of Smart Home Systems and Traffic Light Feedback on Heating Energy Consumption. Curr. J. Appl. Sci. Technol. 2017, 22, 1-18. [CrossRef]

25. Geibler, V.J.; Erdmann, L.; Liedtke, C.; Rohn, H.; Stabe, M.; Berner, S.; Leismann, K.; Schnalzer, K.; Kennedy, K. Exploring the potential of a German Living Lab research infrastructure for the development of low resource products and services. Resources 2014, 3, 575-598. [CrossRef]

26. Meijers, M.H.C.; Noordewier, M.K.; Avramova, Y.R. I just recycled. Can I use the car now? When people continue or discontinue behaving sustainably after an initial sustainable act. In Encouraging Sustainable Behavior: Psychology and the Environment; van Trijp, H.C.M., Ed.; Psychology Press: New York, NY, USA, 2014; pp. 71-80.

27. Laschke, M.; Hassenzahl, M.; Diefenbach, S.; Schneider, T. Keymoment: Initiating Behavior Change through Friendly Friction. In Proceedings of the 8th Nordic Conference on Human-Computer Interaction: Fun, Fast, Foundational, Helsinki, Finland, 26-30 October 2014.

28. Terlau, W.; Hirsch, D. Sustainable Consumption and the Attitude-Behaviour-Gap Phenomenon-Causes and Measurements towards a Sustainable Development. Int. J. Food Syst. Dyn. 2015, 6, 159-174.

29. Liedtke, C.; Hasselkuß, M.; Welfens, M.J.; Nordmann, J.; Baedeker, C. Transformation towards sustainable consumption: Changing patterns through meaning in social practices. In Proceedings of the: 4th International Conference on Sustainability Transitions: IST, Zurich, Switzerland, 19 - 21 June 2013; pp. 705-732.

30. Benyon, D. Designing Interactive Systems: A Comprehensive Guide to HCI and Interaction Design; Addison Wesley: Harlow, UK, 2010.

31. Lockton, D.; Crawford, G.; Singh, D.; Wu, S. Electric Acoustic: Exploring Energy Through Sonic \& Vibration Displays. In Extended Abstracts of the 2019 CHI Conference on Human Factors in Computing Systems; CHI EA '19; ACM: New York, NY, USA, 2019.

32. Rozendaal, M.; Vermeeren, A.; Bekker, T.; Ridder, H. A Research Framework for Playful Persuasion Based on Psychological Needs and Bodily Interaction. In Proceedings of the HBU 2011; Springer: Berlin/Heidelberg, Germany, 2011; Volume 7065, pp. 116-123.

33. Hassenzahl, M. Experience Design: Technology for All the Right Reasons; Morgan and Claypool Publishers: San Rafael, CA, USA, 2010.

34. Thaler, R.H.; Sunstein, C.R. Nudge: Improving Decisions about Health, Wealth, and Happiness; Yale University Press: London, UK, 2009.

35. Dorrestijn, S.; Verbeek, P.P. Technology, wellbeing, and freedom: The legacy of utopian design. Int. J. Des. 2013, 7, 45-56.

36. Norman, D. The Design of Everyday Things. Human Factors and Ergonomics. Manufacturing, 2013; Basic Books: New York, NY, USA, 2013.

37. Norman, D. The Psychology of Everyday Things; Basic Books: New York, NY, USA, 1988.

38. Gibson, J. The Ecological Approach to Visual Perception; Lawrence Erlbaum Associates: Mahwah, NJ, USA, 1979.

39. Fogg, B.J. Persuasive Technology Using Computers to Change what We Think and Do; Morgan Kaufmann Publishers: San Francisco, CA, USA, 2003.

40. Barton, A.; Grüne-Yanoff, T. From libertarian paternalism to nudging-And beyond. Rev. Philos. Psychol. 2015, 6, 341-359. [CrossRef]

41. Thomas, M.; Buckmaster, L. Paternalism in Social Policy-When is it Justifiable? Parliament of Australia, Department of Parliamentary Services: Canberra, Australia, 2010.

42. New, B. Paternalism and Public Policy. Econ. Philos. 1999, 15, 63-83. [CrossRef]

43. Liedtke, C.; Kühlert, M.; Huber, K.; Baedeker, C. Transition Design Guide. Design für Nachhaltigkeit—Gestalten für das Heute und Morgen. Ein Guide für Gestaltung E Entwicklung in Unternehmen, Städten und Quartieren, Forschung und Lehre; Wuppertal Spezial Nr. 55; Wuppertal Institut für Klima, Umwelt, Energie: Wuppertal, Germany, 2019; ISBN 978-3-946356-13-4.

44. Tromp, N.; Hekkert, P. Designing for Society: Products and Services for a Better World; Bloomsbury: London, UK, 2018. 
45. Lilley, D. Design for sustainable behaviour: Strategies and perceptions. Des. Stud. 2009, 30, 704-720. [CrossRef]

46. Fogg, B.J. The Behavior Grid: 35 ways behavior can change. In Proceedings of the Persuasive Technology: Fourth International Conference, Claremont, CA, USA, 26-29 April 2009.

47. Lockton, D. Design with Intent and the Field of Design for Sustainable Behaviour. In Living Labs Design and Assessment of Sustainable Living; Keyson, D., Guerra-Santin, O., Lockton, D., Eds.; Springer International Publishing: Cham, Switzerland, 2017; pp. 75-88.

48. Kuijer, L.; Bakker, C. Of chalk and cheese: Behaviour change and practice theory in sustainable design. Int. J. Sustain. Eng. 2015, 8, 219-230. [CrossRef]

49. Kuijer, L. Practices-oriented design. In Design for Behaviour Change: Theories and Practices of Designing for Change; Niedderer, K., Clune, S., Ludden, G., Eds.; Taylor and Francis: London, UK, 2017; pp. 116-127.

50. Reckwitz, A. Toward a theory of social practices: A development in culturalist theorizing. Eur. J. Soc. Theory 2002, 5, 243-263. [CrossRef]

51. Shove, E.; Pantzar, M.; Watson, M. The Dynamics of Social Practice: Everyday Life and How It Changes; SAGE: Los Angeles, CA, USA; London, UK, 2012.

52. Carver, C.S.; Scheier, M.F. On the Self-Regulation of Behavior; Cambridge University Press: New York, NY, USA, 1989.

53. Kaptelinin, V.; Nardi, B. Acting with Technology: Activity Theory and Interaction Design; MIT Press: Cambridge, MA, USA, 2006.

54. Diefenbach, S.; Hassenzahl, M. Psychologie in der Nutzerzentrierten Produktgestaltung. Mensch-Technik—Interaktion—Erlebnis; Springer: Berlin/Heidelberg, Germany, 2017.

55. Irwin, T. Transition Design: A Proposal for a New Area of Design, Practice, Study and Research. Des. Cult. J. 2015, 7, 229-246. [CrossRef]

56. Schäpke, N.; Stelzer, F.; Caniglia, G.; Bergmann, M.; Wanner, M.; Singer-Brodowski, M.; Loorbach, D.; Olsson, P.; Baedeker, C.; Lang, D. Jointly Experimenting for Transformation? Shaping Real-World Laboratories by Comparing Them. Gaia 2018, 27, 85-96. [CrossRef]

57. Wanner, M.; Hilger, A.; Westerkowski, J.; Rose, M.; Stelzer, F.; Schäpke, N. Towards a Cyclical Concept of Real-World Laboratories. Disp. Rev. 2018, 54, 94-114. [CrossRef]

58. Schneidewind, U.; Augenstein, K.; Stelzer, F.; Wanner, M. Structure Matters: Real-World Laboratories as a New Type of Large-Scale Research Infrastructure. A Framework Inspired by Giddens'StructurationTheory. GAIA 2018, 27, 12-17. [CrossRef]

59. Singer-Brodowski, M.; Beecroft, R.; Parodi, O. Learning in Real-World Laboratories. A SystematicImpulse for Discussion. GAIA 2018, 27, 23-27. [CrossRef]

60. Lockton, D.; Harrison, D.; Stanton, N.A. Models of the user: Designers' perspectives on influencing sustainable behaviour. J. Des. Res. 2012, 10, 7-27. [CrossRef]

61. Boulding, K.E. General systems theory-The skeleton of science. Manag. Sci. 1956, 2, 197-208. [CrossRef]

62. Pask, G. The architectural relevance of cybernetics. Archit. Des. 1969, 7, 494-496.

63. Dubberly, H.; Haque, U.; Pangaro, P. What is interaction? Are there different types? ACM Interact. 2009, 16, 69-75. [CrossRef]

64. Bettin, J.; Buhl, J. Breaking habits: Modeling psychological mechanisms of interventions for energy conservation behavior. In Proceedings of the 4th European Conference on Behaviour and Energy Efficiency (BEHAVE), Coimbra, Portugal, 8-9 September 2016.

65. Lewis, C.; Norman, D. Designing for Error. In User Centered System Design; Norman, D.A., Draper, S.W., Eds.; Lawrence Erlbaum: Hillsdale, NJ, USA, 1986.

66. Simon, H.A. Rational choice and the structure of the environment. Psychol. Rev. 1956, 63, 261-273. [CrossRef] [PubMed]

67. Hunnes, M. Nudging how human behavior is affected by design. Ann. Rev. Policy Des. 2016, 4, 1 .

68. Lockton, D.; Harrison, D.; Stanton, N.A. Design with Intent. 101 Patterns for Influencing Behaviour through Design; GNU General Public Licence by the RNIB: St Margaret's, Middlesex, UK, 2010.

69. Speck, M.; Hasselkuß, M. Sufficiency in social science: Searching potentials for sufficient behavior in a consumerist cultute, Sustainability. Sci. Pract. Policy 2015, 11, 14-32. 
70. Pallot, M.; Trousse, B.; Senach, B.; Scapin, D. Living Lab Research Landscape: From User Centred Design and User Experience towards User Cocreation. In Proceedings of the First European Summer School "Living Labs", Inria (ICT Usage Lab), Userlab, EsoceNet, Universcience, Paris, France, 25-27 August 2010.

71. ENoLL. The European Network of Living Labs. What are Living Labs? Available online: https://enoll.org/ about-us/ (accessed on 7 July 2020).

72. Liedkte, C.; Baedeker, C.; Hasselkuß, M.; Rohn, H.; Grinewitschus, V. User-integrated innovation in Sustainable LivingLabs: An experimental infrastructure for researching and developing sustainable product service systems. J. Clean. Prod. 2015, 97, 106-116.

73. Geibler, V.J.; Piwowar, J.; Greven, A. The SDG-Check: Guiding Open Innovation towards Sustainable Development Goals. Technol. Innov. Manag. Rev. 2019, 9, 20-37. [CrossRef]

74. Baedeker, C.; Liedtke, C.; Welfens, M. Green Economy as a Framework for Product-Service Systems Development: The Role of Sustainable Living Labs. In Living Labs_Design and Assessment of Sustainable Livin; Keyson, D., Guerra-Santin, O., Lockton, D., Eds.; Springer International Publishing: Cham, Switzerland, 2017; pp. 35-51.

75. Keyson, D.; Morrison, M.; Baedeker, C.; Liedtke, C. Living Labs to Accelerate Innovation. In Living Labs-Design and Assessment of Sustainable Living; Keyson, D., Guerra-Santin, O., Lockton, D., Eds.; Springer International Publishing: Cham, Switzerland, 2017; pp. 55-61.

76. Hasselkuß, M.; Baedeker, C.; Liedtke, C. Social Practices as a Main Focus in Living Lab Research. In Living Labs_Design and Assessment of Sustainable Living; Keyson, V., Guerra-Santin, O., Lockton, D., Eds.; Springer International Publishing: Cham, Switzerland, 2017; pp. 23-34.

77. Steen, M. Human-Centered Design as a Fragile Encounter. Des. Issues 2012, 29, 17-30. [CrossRef]

78. ISO 9241-210. Ergonomics of Human System Interaction-Part. 210: Human-Centred Design for Interactive Systems.; International Standardization Organization (ISO): Geneva, Switzerland, 2010.

79. Earthy, J.; Sherwood-Jones, B.; Bevan, N. ISO standards for user centered design and the specification of usability. In Usability in Government Systems: User Experience Design for Citizens and Public Servants; Buie, E., Murray, D., Eds.; Elsevier: London, UK, 2012; pp. 267-283.

80. Norman, D.; Verganti, R. Incremental and Radical Innovation: Design Research vs. Technology and Meaning Change. Des. Issues 2014, 30, 1. [CrossRef]

81. BBSR. Bundesinstitut für Bau-, Stadt- und Raumforschung. Entwicklung einer Strategie zur Unterstützung des Energieeinsparverhaltens von Nutzern/innen in Büro- und Verwaltungsgebäuden. 2019. Available online: https://www.bbsr.bund.de/BBSR/DE/FP/ZB/Auftragsforschung/5EnergieKlimaBauen/ 2017/nutzerverhalten/Endbericht.pdf?_blob=publicationFile\&v=2 (accessed on 8 July 2020).

82. MKULNV. Ministerium für Klimaschutz, Umwelt, Landwirtschaft, Natur- und Verbraucherschutz des Landes Nordrhein-Westfalen. Endbericht für das Vorhaben CO2 Einsparungen durch nutzerzentrierte Energieeffizienzlösungen in Bürogebäuden (EE-Office); MKULNV: Düsseldorf, Germany, 2019.

83. Belussia, L.; Barozzia, B.; Bellazzia, A.; Danzaa, L.; Devitofrancescoa, A.; Fanciullib, C.; Ghellerea, M.; Guazzia, G.; Meronia, I.; Salamonea, F.; et al. Review of performance of zero energy buildings and energy efficiency solutions. J. Build. Eng. 2019, 25, 100772. [CrossRef]

84. BMWi. Bundesministerium für Wirtschaft und Energie. Abschlussbericht der VerbundpartnerRessourceneffizienz im Gebäudebetrieb durch NutzerIntegration und Automation (REGE-NA). Saarbrücken. 2016. Available online: https://www.hs-niederrhein.de/fileadmin/dateien/Institute_und_Kompetenzzentren/ A.U.G.E/REGENA.pdf (accessed on 8 July 2020).

85. Redström, J. Persuasive design: Fringes and foundations. In Proceedings of the International Conference on Persuasive Technology; Springer: Berlin/Heidelberg, Germany, 2006; pp. 112-122.

86. Staats, H.; Van Leeuwen, E.; Wit, A. A longitudinal Study of Informational Interventions to save Energy in an office Building. J. Appl. Behav. Anal. 2000, 33, 101-104. [CrossRef] [PubMed]

87. Matthies, E.; Thomas, D. Nachhaltigkeitsrelevante Routinen am Arbeitsplatz-Voraussetzungen für einen erfolgreichen Wandel. In Wesen und Wege nachhaltigen Konsums. Ergebnisse aus dem Themenschwerpunkt, "vom Wissen Zum Handeln - Neue Wege Zum Nachhaltigen Konsum"; Defila, R., Di Giulio, A., Kaufmann-Hayoz, R., Eds.; Oekom Verlag: München, Germany, 2011; pp. 229-245.

88. Laschke, M.; Hassenzahl, M.; Diefenbach, S. Things with attitude: Transformational products. In Proceedings of the Create11, the Interaction Design Symposium, London, UK, 23 June 2011. 
89. Selinger, E.; Whyte, K. Is there a right way to nudge? The practice and ethics of choice architecture. Sociol. Compass 2011, 5, 923-935. [CrossRef]

90. Schultz, P.W.; Nolan, J.M.; Cialdini, R.B.; Goldstein, N.J.; Griskevicius, V. The Constructive, Destructive, and Reconstructive Power of Social Norms. Psychol. Sci. 2007, 18, 429-434. [CrossRef]

91. Lin, J.; Mamykina, L.; Lindtner, S. Fish'n'steps: Encouraging physical activity with an interactive computer game. In UbiComp 2006: Ubiquitous Computing 8th International Conference; Dourish, P., Friday, A., Eds.; Springer: Orange County, CA, USA, 2006; pp. 261-278.

92. Dillahunt, T.; Becker, G.; Mankoff, J.; Kraut, R. Motivating environmentally sustainable behavior changes with a virtual polar bear. In Proceedings of Pervasive 2008 Workshop on Pervasive Persuasive Technology and Environmental Sustainability; QUT Digital Repository: Sydney, Australia, 2008; pp. 58-62.

93. Ross, J.; Amsel, N.; Beckman, R.; Tomlinson, B. EcoPath: Adding Spatial, Social, and Gaming Contexts to Personal Tracking Systems. Social Code Rep. 2010, 2010, 1.

94. Lockton, D. Design with Intent. A Design Pattern Toolkit for Environmental and Social Behaviour Change. Ph.D. Thesis, Brunel University, London, UK, 2013.

95. Laschke, M. Der Einwand der Dinge. Pleasurable Troublemakers. Ph.D. Thesis, Folkwang Universität der Künste, Essen, Germany, 2014.

96. Stumpf, M. Behavioral Changes and Technical-Organizational Optimizations-A Successful Team in Energy Conservation: Experiences and Insights from Psychological Studies on Energy Use Behavior at Universities. Ph.D. Thesis, Albert-Ludwigs-Universität Freiburg, Freiburg, Germany, 2014.

97. BBSR. Bundesinstitut für Bau-, Stadt- und Raumforschung im Bundesamt für Bauwesen und Raumordnung (BBR). Quantifizierung von Rebound-Effekten bei der energetischen Sanierung von Nichtwohngebäuden/Bundesliegenschaften. Energiekennwerte, Prebound-Effekt und Verhalten der Nutzer/innen vor Einer Energetischen Sanierung. BBSR-Online-Publikation 02/2017, Bonn. Available online: https://www.bbsr.bund.de/BBSR/DE/veroeffentlichungen/bbsr-online/2017/bbsr-online-02-2017.html (accessed on 8 July 2020).

98. Tsafack, W.; Christian, A.; Naumann, S.; Gollmer, K.; Ebner, L.; Michels, R.; Koch, P.; Guldner, A.; Eigenstetter, M.; Jähn, V.; et al. Resource Efficiency in Buildings trough Automation and User Integration (REGENA). In Proceedings of the 27th Conference on Environmental Informatics-Informatics for Environmental Protection, Sustainable Development and Risk Management; Page, B., Fleischer, A., Göbel, J., Wohlgemuth, V., Eds.; Shaker Verlag: Aachen, Germany, 2013.

99. Bundesministerium für Verkehr, Innovation und Technologie. Build to Satisfy: Modellierung des NutzerInnenverhaltens in Niedrigst- und Plusenergiegebäuden. Berichte aus Energie- und Umweltforschung 32/2014, Wien. Available online: https://nachhaltigwirtschaften.at/resources/hdz_pdf/berichte/endbericht_ 1432_build_to_satisfy.pdf (accessed on 8 July 2020).

100. EnergieAgentur.NRW, “mission E”. Available online: http://www.missione.nrw/index.php (accessed on 8 July 2020).

101. Delmas, M.; Fischlein, M.; Asensio, O. Information strategies and energy conservation behavior: A meta-analysis of experimental studies from 1975 to 2012. Energy Policy 2012, 61, 729-739. [CrossRef]

102. Bremer Energie-Konsens $\mathrm{GmbH}$, Modellprojekt Mitarbeitereinbindung. Available online: http://www. energiekonsens.de/mitarbeitereinbindung-unternehmen.html (accessed on 8 July 2020).

103. Ruhr Universität Bochum, "CHANGE". Available online: http://www.change-energie.de/ (accessed on 8 July 2020).

104. co2online $\mathrm{GmbH}$, Energiesparcup/European Enterprises' Climate Cup. Available online: http://www. energiesparcup.biz/ (accessed on 8 July 2020).

105. Albert-Ludwigs-Universität Freiburg, “Dezentrale Monetäre Anreize zum Energiesparen”. Available online: http://www.nachhaltige.uni-freiburg.de/klimaschutz/dezmon-2010 (accessed on 8 July 2020).

106. Da Silva, O.; Crilly, N.; Hekkert, P. Can a Light Switch Be Beautiful? Aesthetic Appreciation of Products as Means. In Proceedings of the Conference of the Design Research Society, Umeå, Sweden, 16-19 June 2014.

107. Duffy, S.; Verges, M. It matters a hole lot: Perceptual affordances of waste containers influence recycling compliance. Environ. Behav. 2008, 41, 741-749. [CrossRef] 
108. Bundesinstitut für Bau-, Stadt- und Raumforschung (BBSR) im Bundesamt für Bauwesen und Raumordnung (BBR). Sondierungsstudie zur Quantifizierung von Rebound-Effekten bei der energetischen Sanierung von Nichtwohngebäuden/Bundesliegenschaften. BBSR-Online-Publikation 01/2015, Bonn. Available online: http://www.irbnet.de/daten/baufo/20150043/Endbericht_DL_ON012015.pdf (accessed on 8 July 2020).

109. Wohlgemuth, A. Efficient Energy Input by a User Integration with Coupled Documentation on the Basis of Smart Media Counters. Fallstudie am Forschungszentrum Jülich. Bachelor's Thesis, Hochschule Bochum, Froschungszentrum Jülich, Bochum, Germany, 2017.

110. Berliner Energieagentur $\mathrm{GmbH}$, Anstoß Energie_Energiesparen am Arbeitsplatz. Available online: http:// www.berliner-e-agentur.de/beratung-information/anstoss-energie-energiesparen-am-arbeitsplatz (accessed on 8 July 2020).

111. Murtagh, N.; Nati, M.; Headley, W.; Gatersleben, B.; Gluhak, A.; Imran, M.A.; Uzzel, D. Individual energy use and feedback in an office setting: A field trial. Energy Policy 2013, 62, 717-728. [CrossRef]

112. Abrahamse, W.; Steg, L. Social influence approaches to encourage resource conservation: A meta-analysis. Glob. Environ. Chang. 2013, 23, 1773-1785. [CrossRef]

113. Klonek, F.E.; Kauffeld, S. Talking with consumers about energy reductions: Recommendations from a motivational interviewing perspective. Front. Psychol. 2015, 6, 252. [CrossRef]

114. Siero, F.; Bakker, A.; Dekker, G.; Burg, M. Changing organizational energy consumption behaviour through comparative feedback. J. Environ. Psychol. 1996, 16, 235-246. [CrossRef]

115. European Environment Agency. Achieving Energy Efficiency Through Behavior Change: What Does it Take? EEA Technical Report No 5/2013. Available online: https://www.eea.europa.eu/publications/achievingenergy-efficiency-through-behaviour (accessed on 8 July 2020).

116. Stadt Aachen: e2watch. Available online: https://stadt-aachen.e2watch.de/ (accessed on 8 July 2020).

117. Shiraishi, M.; Washio, Y.; Takayama, C.; Lehdonvirta, V.; Kimura, H.; Nakajima, T. Using individual, social and economic persuasion techniques to reduce $\mathrm{CO}_{2}$ emissions in a family setting. In Proceedings of the 4 th International Conference on Persuasive Technology, Claremont, CA, USA, 26-29 April; pp. 1-8.

118. Wilson, C.; Dowlatabadi, H. Models of decision making and residential energy use. Ann. Rev. Environ. Resour. 2007, 2, 169-203. [CrossRef]

119. EnergieAgentur.NRW: Aktionswoche, Efit. Available online: http://www.energieagentur.nrw/klimaschutz/ efit/ (accessed on 8 July 2020).

(C) 2020 by the authors. Licensee MDPI, Basel, Switzerland. This article is an open access article distributed under the terms and conditions of the Creative Commons Attribution (CC BY) license (http://creativecommons.org/licenses/by/4.0/). 